\title{
Metal-Metal Cooperation in the Oxidation of a Flapping Platinum Butterfly by Haloforms: Experimental and Theoretical Evidence
}

\author{
Violeta Sicilia,* Lorenzo Arnal, Sara Fuertes, * Antonio Martín, and Miguel Baya \\ Cite This: https://dx.doi.org/10.1021/acs.inorgchem.0c01701 \\ Read Online
}

ABSTRACT: The model 1-DFT for the butterfly complex $\left[\left\{\mathrm{Pt}\left(\mathrm{C}^{\wedge} \mathrm{C}^{*}\right)(\mu \text {-pz })\right\}_{2}\right](\mathbf{1}$; $\mathrm{HC}^{\wedge} \mathrm{C}^{*}=1$-(4-(ethoxycarbonyl)phenyl)-3-methyl-1 $\mathrm{H}$-imidazol-2-ylidene) shows two minima in the potential energy surface of the ground state in acetone solution: the butterfly-wing-spreading molecules $1-\mathrm{s},\left(d_{\mathrm{Pt}-\mathrm{Pt}} \approx 3.20 \AA\right)$ and the wing-folding molecules 1-f $\left(d_{\mathrm{Pt}-\mathrm{Pt}} \leq 3.00 \AA\right)$. Both minima are very close in energy $\left(\Delta G^{\circ}=1.7\right.$ $\mathrm{kcal} / \mathrm{mol}$ ) and are connected through a transition state, which lies only $1.9 \mathrm{kcal} / \mathrm{mol}$ above 1-s and $0.2 \mathrm{kcal} / \mathrm{mol}$ above 1-f. These very low barriers support a fast interconversion process, resembling a butterfly flapping, and the presence of both conformers in acetone solution. However, the 1-f ratio is so low that it is undetectable in the excitation and emission spectra of 1 in 2-MeTHF of diluted solutions $\left(10^{-5} \mathrm{M}\right)$ at $77 \mathrm{~K}$, while it is seen in more concentrated solutions $\left(10^{-3} \mathrm{M}\right)$. In acetone solution, $\mathbf{1}$ undergoes a $[2 \mathrm{c}, 2 \mathrm{e}]$ oxidation by $\mathrm{CHX}_{3}(\mathrm{X}=\mathrm{Cl}$, $\mathrm{Br})$ in the sunlight to render the $\mathrm{Pt}_{2}(\mathrm{III}, \mathrm{III})$ compounds $\left.\left[\left\{\mathrm{Pt}\left(\mathrm{C}^{\wedge} \mathrm{C}^{*}\right)(\mu-\mathrm{pz}) \mathrm{X}\right)\right\}_{2}\right](\mathrm{X}=\mathrm{Cl}(\mathbf{2}-\mathrm{Cl}), \mathrm{Br}(\mathbf{2}-\mathrm{Br}))$. In concentrated solutions, 1 can react with $\mathrm{CHCl}_{3}$ under blue light to give $2-\mathrm{Cl}$ and with $\mathrm{CHBr}_{3}$ in the dark, the latter rendering the compound $\left[\mathrm{BrPt}\left(\mathrm{C}^{\wedge} \mathrm{C}^{*}\right)(\mu-\mathrm{pz})_{2} \mathrm{Pt}\left(\mathrm{C}^{\wedge} \mathrm{C}^{*}\right) \mathrm{CHBr}_{2}\right](3-\mathrm{Br})$ or mixtures of $\mathbf{2}-\mathrm{Br}$ and 3-Br if the reaction is performed under an argon atmosphere or in the air, respectively. Mechanistic studies showed that in concentrated solutions the oxidation processes follow a radical mechanism being the MMLCT-based species 1-f, those which trigger the reaction of $\mathbf{1}$ with $\mathrm{CHBr}_{3}$ and $\mathrm{CHCl}_{3}$. In the ground state $\left(\mathrm{S}_{\mathrm{ff}}\right)$, it promotes the thermal oxidation of $\mathbf{1}$ by $\mathrm{CHBr}_{3}$ and in the first singlet excited state $\left(\mathrm{S}_{1 \mathrm{f}}\right)$ the blue-light-driven photooxidation of $\mathbf{1}$ by $\mathrm{CHCl}_{3}$. Complexes, 2-Cl, 2-Br, and 3-Br were selectively obtained and fully characterized, showing $\mathrm{Pt}-\mathrm{Pt}$ distances (ca. 2.6 $\AA$ ) shorter than that of the starting complex, 1. They are, together with the analogous $\left.\left[\left\{\mathrm{Pt}\left(\mathrm{C}^{\wedge} \mathrm{C}^{*}\right)(\mu \text {-pz }) \mathrm{I}\right)\right\}_{2}\right]$ and $\left[\operatorname{IPt}\left(\mathrm{C}^{\wedge} \mathrm{C}^{*}\right)(\mu-\right.$ $\left.\mathrm{pz})_{2} \mathrm{Pt}\left(\mathrm{C}^{\wedge} \mathrm{C}^{*}\right) \mathrm{CHI}_{2}\right]$, the only dinuclear metal-metal-bonded $\mathrm{Pt}^{\mathrm{III}}\left(\mu-\mathrm{pz}_{2}\right)_{2} \mathrm{Pt}^{\mathrm{III}}$ compounds reported to date.

\section{INTRODUCTION}

Cooperative effects between the adjacent $\mathrm{d}^{8}$ metal centers of dinuclear complexes have been reported to facilitate the formation of stabilizing metal-metal bonds in the intermediates of catalytic reactions, involving oxidative additionreductive elimination processes, which allows pathways and products unavailable from mononuclear complexes. ${ }^{1}$ $\mathrm{Pd}_{2}(\mathrm{III}, \mathrm{III})$ or $\mathrm{Rh}_{2}(\mathrm{II}, \mathrm{II})$ species are some examples of lowenergy transition states for $\mathrm{C}-\mathrm{H}$ functionalization ${ }^{2,3}$ or alkene hydroformylation ${ }^{4}$ reactions, respectively. In the chemistry of dinuclear platinum(II) complexes it is well-known that $\left[\mathrm{Pt}_{2}(\mathrm{POP})_{4}\right]^{4-}(\mathrm{POP}=$ pyrophosphito $)$ exhibits a rich luminescence and photochemistry associated with the presence of $\mathrm{Pt} \cdots \mathrm{Pt}$ interactions, resulting in short intermetallic separation $(2.925 \AA)$. This complex undergoes thermal twocenter-two-electron $[2 \mathrm{c}, 2 \mathrm{e}]$ oxidative addition $(\mathrm{OA}){ }^{5}$ but the diradical excited state ${ }^{3}\left[5 \mathrm{~d} \sigma^{*} \rightarrow 6 \mathrm{p} \sigma\right]$, with enhanced metal-metal-bonding interactions, is the active species for the photoinduced dehydrogenation of alcohols to aldehydes/ ketones. $^{6}$

Furthermore, the half-lantern compound $[\{\mathrm{Pt}(\mathrm{bzq})(\mu$ $\left.\left.\left.\mathrm{N}^{\wedge} \mathrm{S}\right)\right\}_{2}\right]$ (bzq = benzo $[h]$ quinoline, $\mathrm{HN}^{\wedge} \mathrm{S}=2$-mercaptopyrimidine) also undergoes $[2 \mathrm{c}, 2 \mathrm{e}]$ thermal oxidative addition (OA) of $\mathrm{CH}_{3} \mathrm{I}$ and haloforms $\mathrm{CHX}_{3}(\mathrm{X}=\mathrm{Br}, \mathrm{I})$, but the MMLCT $5 \mathrm{~d} \sigma^{*} \rightarrow \pi^{*}(\mathrm{bzq})$ excited state, available upon excitation with green LEDs, is the active state for the photooxidation of $\left[\left\{\mathrm{Pt}(\mathrm{bzq})\left(\mu-\mathrm{N}^{\wedge} \mathrm{S}\right)\right\}_{2}\right]$ with $\mathrm{CHCl}_{3}{ }^{7}$

In this sense, pyrazolate ligands have a proven ability to hold two metal atoms in close proximity, while they permit a wide range of intermetallic separations. Cooperative effects between the two metal centers have been reported for the $[2 c, 2 e]$ OA of many electrophiles to $\operatorname{Ir}_{2}(\mathrm{I}, \mathrm{I})$ bis-pyrazolate bridging complexes. ${ }^{8}$ In the case of pyrazolate-bridged dinuclear $\mathrm{Pt}(\mathrm{II})$ complexes $[2 \mathrm{c}, 2 \mathrm{e}] \mathrm{OA}$ reactions have been never reported. The chemistry has been focused on complexes such as $\left[\left\{\mathrm{Pt}\left(\mathrm{N}^{\wedge} \mathrm{E}\right)(\mu-\mathrm{Rpz})\right\}_{2}\right]^{2+}(\mathrm{E}=\mathrm{N}$, diimines or pyridylpyrazolate; $\mathrm{E}=\mathrm{C}$, pyridyl-NHC $),{ }^{9-15}\left[\left\{\mathrm{Pt}\left(\mathrm{C}^{\wedge} \mathrm{N}\right)(\mu-\mathrm{Rpz})\right\}_{2}\right]\left(\mathrm{C}^{\wedge} \mathrm{N}=\right.$ $\mathrm{C}, \mathrm{N}$-cyclometalated ligand $),{ }^{16-23}$ and $\left[\left\{\mathrm{Pt}\left(\mathrm{C}^{\wedge} \mathrm{C}^{*}\right)(\mu \text {-Rpz })\right\}_{2}\right]$ $\left(\mathrm{C}^{\wedge} \mathrm{C}^{*}=\text { phenyl-NHC }\right)^{24}$ due to their phosphorescent behavior. Most studies have addressed the control of the photoluminescence properties of the complexes $\left[\left\{\mathrm{Pt}\left(\mathrm{C}^{\wedge} \mathrm{N}\right)(\mu\right.\right.$ $\left.\mathrm{Rpz})\}_{2}\right]$, dubbed "molecular butterflies", by tuning the $\mathrm{Pt} \cdots \mathrm{Pt}$

Received: June 9, 2020 


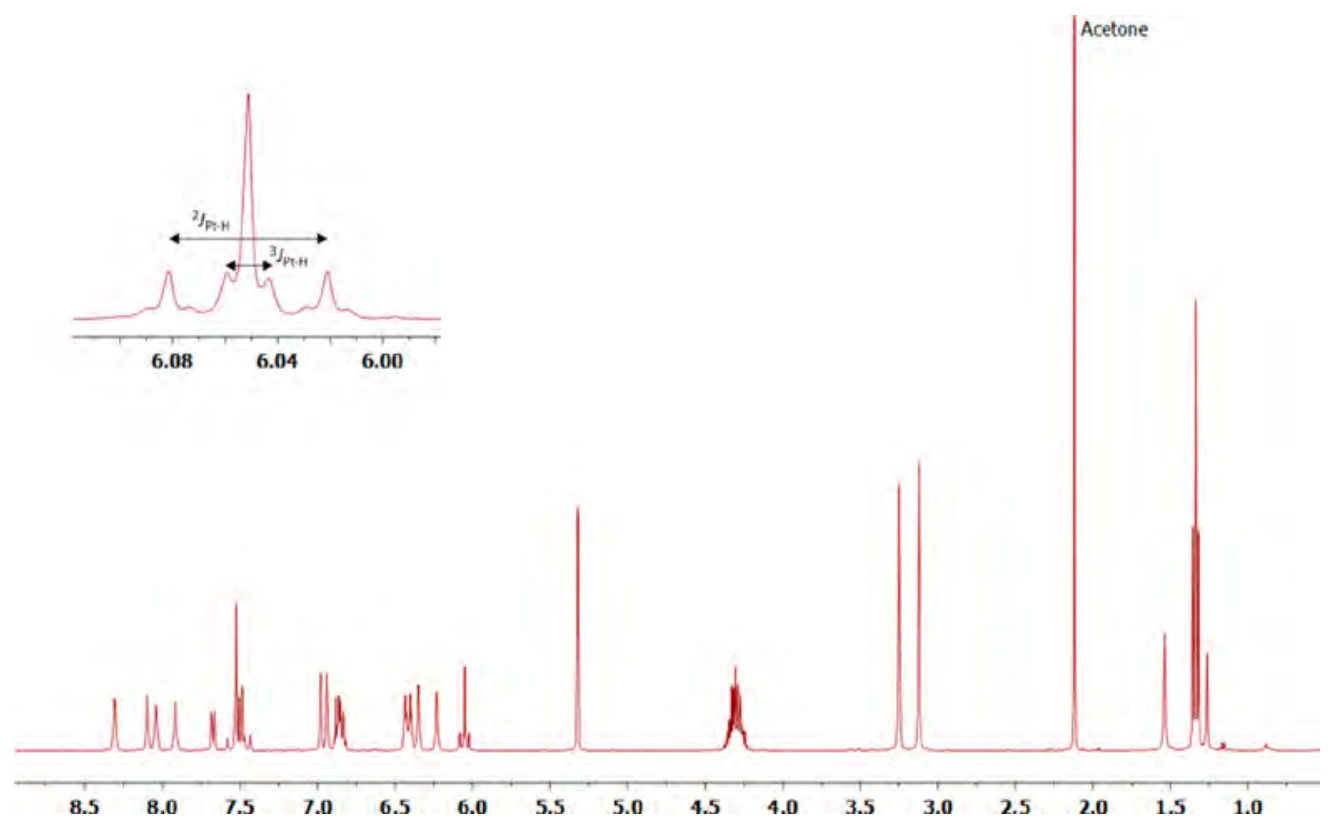

Figure 1. ${ }^{1} \mathrm{H}$ NMR spectrum of $3-\mathrm{Br}$ in $\mathrm{CD}_{2} \mathrm{Cl}_{2}$.

separation; they can be modulated by controlling the bulkiness of the bridging pyrazolates (the butterfly body) and the bulkiness and electronic properties of the $\mathrm{C}^{\wedge} \mathrm{N}$ group (the butterfly wings). ${ }^{16-2}$

In the course of our research we prepared the butterfly compound $\left[\left\{\mathrm{Pt}\left(\mathrm{C}^{\wedge} \mathrm{C}^{*}\right)(\mu-\mathrm{pz})\right\}_{2}\right] \quad$ (1) $\left(\mathrm{HC}^{\wedge} \mathrm{C}^{*}=1-(4-\right.$ (ethoxycarbonyl)phenyl)-3-methyl- $1 \mathrm{H}$-imidazol-2-ylidene), and the reaction mechanism of 1 with $\mathrm{CHI}_{3}$ was deeply studied. $^{25}$ To complete this piece of chemistry, we studied the reaction of 1 with $\mathrm{CHCl}_{3}$ and $\mathrm{CHBr}_{3}$ and the mechanisms of the thermal oxidation and photooxidation of 1 with $\mathrm{CHBr}_{3}$ and $\mathrm{CHCl}_{3}$ both experimentally and theoretically. Our results showed that the $\mathrm{C}^{\wedge} \mathrm{C}^{*}$ basicity and the cooperative effects between the two adjacent metal centers in the $\mathrm{Pt}_{2}$ (II,II) species are crucial to promote the $\mathrm{C}-\mathrm{X}(\mathrm{X}=\mathrm{Cl}, \mathrm{Br})$ activation. Furthermore, the oxidation products $\left.\left[\left\{\mathrm{Pt}\left(\mathrm{C}^{\wedge} \mathrm{C}^{*}\right)(\mu-\mathrm{pz}) \mathrm{X}\right)\right\}_{2}\right]$ $(\mathrm{X}=\mathrm{Cl}(\mathbf{2}-\mathrm{Cl}), \mathrm{Br}(\mathbf{2}-\mathrm{Br}))$ and $\left[\mathrm{BrPt}\left(\mathrm{C}^{\wedge} \mathrm{C}^{*}\right)(\mu-\mathrm{pz})_{2} \mathrm{Pt}-\right.$ $\left.\left(\mathrm{C}^{\wedge} \mathrm{C}^{*}\right) \mathrm{CHBr}_{2}\right]$ (3-Br) have been fully characterized, including their $\mathrm{X}$-ray single-crystal structures.

\section{EXPERIMENTAL SECTION}

General information about procedures and instrumentation, NMR spectra for characterization, DFT and TD-DFT calculations, and Xray structure determinations (CCDC 1985166-1985168) are available in the Supporting Information. The starting material $\left[\left\{\mathrm{Pt}\left(\mathrm{C}^{\wedge} \mathrm{C}^{*}\right)(\mu-\mathrm{pz})\right\}_{2}\right]$ (1) was prepared byfollowing the published procedure and isolated in a $1 / 9$ syn/anti ratio. ${ }^{25}$

Synthesis and Characterization of syn-/anti-[ $\left\{\mathrm{Pt}\left(\mathrm{EtO}_{2} \mathrm{C}-\right.\right.$ $\left.\left.\left.\left.\mathrm{C}^{\wedge} \mathrm{C}^{*}\right)(\boldsymbol{\mu}-\mathrm{pz}) \mathrm{Cl}\right)\right\}_{2}\right]$ (2-Cl). Compound A $(67.9 \mathrm{mg}, 0.069 \mathrm{mmol})$ was allowed to react in $\mathrm{CHCl}_{3}(15 \mathrm{~mL})$ in ambient light at rt for 7.5 $\mathrm{h}$. The resulting yellow solution was concentrated to $\sim 5 \mathrm{~mL}$, and 10 $\mathrm{mL}$ of hexane was added to the residue to give 2-Cl-anti (96\%)/ 2-Clsyn (4\%) as a yellow solid. Yield: $65 \mathrm{mg}, 89 \%$. Anal. Calcd for $\mathrm{C}_{32} \mathrm{H}_{32} \mathrm{Cl}_{2} \mathrm{~N}_{8} \mathrm{O}_{4} \mathrm{Pt}_{2}$ : C, 36.47; $\mathrm{H}, 3.06 ; \mathrm{N}, 10.63$. Found: C, 36.03; $\mathrm{H}$, 2.83; $\mathrm{N}, 10.36$. ${ }^{1} \mathrm{H}$ NMR data for 2-Cl-anti $(400 \mathrm{MHz}$, methylene chloride- $d_{2} ; J$ values in $\left.\mathrm{Hz}\right): \delta 7.97-7.92\left(\mathrm{~m}, 2 \mathrm{H}, \mathrm{H}_{3^{\prime}}, \mathrm{pz}\right), 7.86-7.81$ $\left(\mathrm{m}, 2 \mathrm{H}, \mathrm{H}_{5^{\prime}}, \mathrm{pz}\right), 7.58\left(\mathrm{dd},{ }^{3} \mathrm{~J}_{\mathrm{H} 9, \mathrm{H} 10}=8.2,{ }^{4} \mathrm{~J}_{\mathrm{H} 9, \mathrm{H} 7}=1.7,2 \mathrm{H}, \mathrm{H}_{9}\right), 7.50$ $\left(\mathrm{d},{ }^{4} J_{\mathrm{H} 7, \mathrm{H} 9}=1.7,{ }^{3} J_{\mathrm{H} 7, \mathrm{Pt}}=39.6,2 \mathrm{H}, \mathrm{H}_{7}\right), 6.99\left(\mathrm{~d},{ }^{3} J_{\mathrm{H} 3, \mathrm{H} 2}=2.2,2 \mathrm{H}\right.$, $\left.\mathrm{H}_{2}\right), 6.90\left(\mathrm{~d},{ }^{3} \mathrm{~J}_{\mathrm{H} 10, \mathrm{H} 9}=8.2,2 \mathrm{H}, \mathrm{H}_{10}\right), 6.42-6.36\left(\mathrm{~m}, 4 \mathrm{H}, \mathrm{H}_{4^{\prime}}(\mathrm{pz})\right.$ and $\left.\mathrm{H}_{3}\right), 4.30\left(\mathrm{q},{ }^{3} \mathrm{~J}_{\mathrm{H}, \mathrm{H}}=7.1,4 \mathrm{H}, \mathrm{CH}_{2}, \mathrm{CO}_{2} \mathrm{Et}\right), 3.30\left(\mathrm{~s}, 6 \mathrm{H}, \mathrm{H}_{4}\right), 1.33(\mathrm{t}$, $\left.{ }^{3} J_{\mathrm{H}, \mathrm{H}}=7.1,6 \mathrm{H}, \mathrm{CH}_{3}, \mathrm{CO}_{2} \mathrm{Et}\right) .{ }^{1} \mathrm{H}$ NMR data for 2-Cl-syn: $\delta 3.63(\mathrm{~s}$, $\left.6 \mathrm{H}, \mathrm{H}_{4}\right)$; other resonances were not detected. ${ }^{13} \mathrm{C}\left\{{ }^{1} \mathrm{H}\right\}$ NMR plus HMBC and HSQC for 2-Cl-anti (101 MHz, methylene chloride- $\left.d_{2}\right)$ : $\delta 166.3$ (s, 2C, $\mathrm{CO}_{2} \mathrm{Et}$ ), 146.7 (s, 2C, $\mathrm{C}_{1}$ ), 136.7 and 134.7 (s, 4C, $\mathrm{CH}, \mathrm{pz}), 133.7$ (s, 2C, $\mathrm{H}_{7}$ ), 127.8 (s, 2C, $\mathrm{C}_{9}$ ), 123.6 (s, 2C, $\mathrm{C}_{3}$ ), 115.1 $\left(\mathrm{s}, 2 \mathrm{C}, \mathrm{C}_{2}\right), 111.4\left(\mathrm{~s}, 2 \mathrm{C}, \mathrm{C}_{10}\right), 106.3\left(\mathrm{~s}, 2 \mathrm{C}, \mathrm{C}_{4}\right), 61.6\left(\mathrm{~s}, 2 \mathrm{C}, \mathrm{CH}_{2}\right.$, $\left.\mathrm{CO}_{2} \mathrm{Et}\right), 37.1$ (s, 2C, $\left.\mathrm{C}_{4}\right), 14.8\left(\mathrm{~s}, 2 \mathrm{C}, \mathrm{CH}_{3}, \mathrm{CO}_{2} \mathrm{Et}\right) .{ }^{195} \mathrm{Pt}\left\{{ }^{1} \mathrm{H}\right\} \mathrm{NMR}$ $\left(85.6 \mathrm{MHz}\right.$, methylene chloride- $\left.d_{2}\right): \delta-2441 \mathrm{ppm}$. MS (MALDI+): $m / z$ 982.3 $\left[\left\{\mathrm{Pt}\left(\mathrm{EtO}_{2} \mathrm{C}_{-} \mathrm{C}^{\wedge} \mathrm{C}^{*}\right)(\mu-\mathrm{pz})\right\}_{2}\right], 1017.2\left[\left\{\mathrm{Pt}\left(\mathrm{EtO}_{2} \mathrm{C}^{\wedge} \mathrm{C}^{\wedge} \mathrm{C}^{*}\right)-\right.\right.$ $\left.(\mu-\mathrm{pz})\}_{2} \mathrm{Cl}\right]^{+}$. MS (MALDI-): $m / z 1089.3\left[\left\{\mathrm{Pt}\left(\mathrm{EtO}_{2} \mathrm{C}_{-} \mathrm{C}^{\wedge} \mathrm{C}^{*}\right)(\mu-\right.\right.$ pz) $\left.\mathrm{Cl}\}_{2} \mathrm{Cl}\right]^{-}$.

Synthesis and Characterization of syn-/anti-[ $\left[\mathrm{Pt}\left(\mathrm{EtO}_{2} \mathrm{C}-\right.\right.$ $\left.\left.\left.\left.\mathbf{C}^{\wedge} \boldsymbol{C}^{*}\right)(\boldsymbol{\mu}-\mathbf{p z}) \mathrm{Br}\right)\right\}_{2}\right](2-\mathrm{Br}) . \mathrm{CHBr}_{3}(38 \mu \mathrm{L}, 0.10 \mathrm{mmol})$ was added to a solution of $1(43 \mathrm{mg}, 0.044 \mathrm{mmol})$ in acetone $(10 \mathrm{~mL})$ and allowed to react in ambient light at $\mathrm{rt}$ for $2 \mathrm{~h}$. Then the solvent was removed under vacuum, the residue was treated with hexane, and this solution was filtered to give 2-Br-anti (96\%)/ 2-Br-syn (4\%) as a yellowish orange solid. Yield: $45 \mathrm{mg}, 90 \%$. Anal. Calcd for $\mathrm{C}_{32} \mathrm{H}_{32} \mathrm{Br}_{2} \mathrm{~N}_{8} \mathrm{O}_{4} \mathrm{Pt}_{2}$ : C, 33.64; $\mathrm{H}, 2.82 ; \mathrm{N}, 9.81$. Found: $\mathrm{C}, 33.29 ; \mathrm{H}$, 2.86; $\mathrm{N}$, 9.31. ${ }^{1} \mathrm{H}$ NMR data for 2 -Br-anti $(400 \mathrm{MHz}$, methylene chloride- $d_{2} ; J$ values in $\left.\mathrm{Hz}\right): \delta 8.00-7.95\left(\mathrm{~m}, 2 \mathrm{H}, \mathrm{H}_{3^{\prime}}, \mathrm{pz}\right), 7.87-7.82$ $\left(\mathrm{m}, 2 \mathrm{H}, \mathrm{H}_{5^{\prime}}, \mathrm{pz}\right), 7.56\left(\mathrm{dd},{ }^{3} J_{\mathrm{H} 9, \mathrm{H} 10}=8.1,{ }^{4} J_{\mathrm{H} 9, \mathrm{H} 7}=1.7,2 \mathrm{H}, \mathrm{H}_{9}\right), 7.49$ $\left(\mathrm{d},{ }^{4} J_{\mathrm{H} 7, \mathrm{H} 9}=1.7,{ }^{3} J_{\mathrm{H} 7, \mathrm{Pt}}=40.0,2 \mathrm{H}, \mathrm{H}_{7}\right), 6.98\left(\mathrm{~d},{ }^{3} J_{\mathrm{H} 3, \mathrm{H} 2}=2.2,2 \mathrm{H}\right.$, $\left.\mathrm{H}_{2}\right), 6.90\left(\mathrm{~d},{ }^{3} \mathrm{~J}_{\mathrm{H} 10, \mathrm{H} 9}=8.2,2 \mathrm{H}, \mathrm{H}_{10}\right), 6.40-6.34\left(\mathrm{~m}, 4 \mathrm{H}, \mathrm{H}_{4^{\prime}}(\mathrm{pz})\right.$ and $\left.\mathrm{H}_{3}\right), 4.30\left(\mathrm{q},{ }^{3} \mathrm{~J}_{\mathrm{H}, \mathrm{H}}=7.1,4 \mathrm{H}, \mathrm{CH}_{2}, \mathrm{CO}_{2} \mathrm{Et}\right), 3.28\left(\mathrm{~s}, 6 \mathrm{H}, \mathrm{H}_{4}\right), 1.33(\mathrm{t}$, $\left.{ }^{3} J_{\mathrm{H}, \mathrm{H}}=7.1,6 \mathrm{H}, \mathrm{CH}_{3}, \mathrm{CO}_{2} \mathrm{Et}\right) .{ }^{1} \mathrm{H} \mathrm{NMR}$ data for 2-Br-syn: $\delta 3.60(\mathrm{~s}$, $\left.6 \mathrm{H}, \mathrm{H}_{4}\right)$; other resonances were not detected. ${ }^{13} \mathrm{C}\left\{{ }^{1} \mathrm{H}\right\}$ NMR plus HMBC and HSQC for 2-Br-anti (101 MHz, methylene chloride- $\left.d_{2}\right)$ : $\delta 166.3$ (s, 2C, $\mathrm{CO}_{2} \mathrm{Et}$ ), 147.1 (s, 2C, $\mathrm{C}_{5}$ ), 146.4 (s, 2C, $\mathrm{C}_{1}$ ), 137.3 and 135.7 (s, 4C, CH, pz), $133.8\left(\mathrm{~s}, 2 \mathrm{C}, \mathrm{C}_{7}\right), 127.6\left(\mathrm{~s}, 2 \mathrm{C}, \mathrm{C}_{9}\right), 127.5$ and $124.3\left(\mathrm{~s}, 4 \mathrm{C}, \mathrm{C}_{6}\right.$ and $\left.\mathrm{C}_{8}\right), 123.5\left(\mathrm{~s}, 2 \mathrm{C}, \mathrm{C}_{3}\right), 115.1\left(\mathrm{~s}, 2 \mathrm{C}, \mathrm{C}_{2}\right)$, $111.3\left(\mathrm{~s}, 2 \mathrm{C}, \mathrm{C}_{10}\right), 106.3\left(\mathrm{~s}, 2 \mathrm{C}, \mathrm{C}_{4^{\prime}}\right), 61.6\left(\mathrm{~s}, 2 \mathrm{C}, \mathrm{CH}_{2}, \mathrm{CO}_{2} \mathrm{Et}\right), 37.1$ (s, 2C, $\left.\mathrm{C}_{4}\right), 14.6$ (s, 2C, $\left.\mathrm{CH}_{3}, \mathrm{CO}_{2} \mathrm{Et}\right) .{ }^{195} \mathrm{Pt}\left\{{ }^{1} \mathrm{H}\right\} \mathrm{NMR}(85.6 \mathrm{MHz}$, methylene chloride- $\left.d_{2}\right): \delta-2675$ ppm. MS (MALDI+): $\mathrm{m} / z 982.2$ $\left[\left\{\mathrm{Pt}\left(\mathrm{EtO}_{2} \mathrm{C}-\mathrm{C}^{\wedge} \mathrm{C}^{*}\right)(\mu-\mathrm{pz})\right\}_{2}\right], \quad 1063.2 \quad\left[\left\{\mathrm{Pt}\left(\mathrm{EtO}_{2} \mathrm{C}-\mathrm{C}^{\wedge} \mathrm{C}^{*}\right)(\mu-\right.\right.$ $\left.\mathrm{pz})\}_{2} \mathrm{Br}\right]^{+}$.

Synthesis and Characterization of anti-[BrPt$\left(\mathrm{EtO}_{2} \mathrm{C}-\mathrm{C}^{\wedge} \mathrm{C} *\right)(\mu-$ pz) $\left.{ }_{2} \mathrm{Pt}\left(\mathrm{EtO}_{2} \mathrm{C}-\mathrm{C}^{\wedge} \mathrm{C}^{*}\right)\left(\mathrm{CHBr}_{2}\right)\right]$ (3-Br). $\mathrm{CHBr}_{3}(29.0 \mu \mathrm{L}, 0.33 \mathrm{mmol})$ was added in the dark to a solution of $\mathbf{A}(81.4 \mathrm{mg}, 0.08 \mathrm{mmol})$ in degassed acetone $(7 \mathrm{~mL})$ at $\mathrm{rt}$ under an argon atmosphere and allowed to react for $30 \mathrm{~min}$. Then the solvent was removed under vacuum, the residue was treated with $n$-hexane, and this solution was filtered to give 3-Br as a yellow solid. Yield: $70.4 \mathrm{mg}, 69 \%$. Anal. Calcd for $\mathrm{C}_{33} \mathrm{H}_{33} \mathrm{Br}_{3} \mathrm{~N}_{8} \mathrm{O}_{4} \mathrm{Pt}_{2}$ : C, 32.08; $\mathrm{H}, 2.69 ; \mathrm{N}, 9.07$. Found: C, 32.40; $\mathrm{H}, 2.96 ; \mathrm{N}, 8.67 .{ }^{1} \mathrm{H}$ NMR data $\left(400 \mathrm{MHz}\right.$, methylene chloride- $d_{2} ; J$ 
values in $\mathrm{Hz}): \delta 8.31\left(\mathrm{~d},{ }^{3} \mathrm{~J}_{\mathrm{H}, \mathrm{H}}=2.2,{ }^{3} J_{\mathrm{H}, \mathrm{Pt}}=5.0,1 \mathrm{H}, \mathrm{pz}\right), 8.10(\mathrm{~d}$, $\left.{ }^{3} J_{\mathrm{H}, \mathrm{H}}=2.3,{ }^{3} J_{\mathrm{H}, \mathrm{Pt}}=5.6,1 \mathrm{H}, \mathrm{pz}\right), 8.04\left(\mathrm{~d},{ }^{3} \mathrm{~J}_{\mathrm{H}, \mathrm{H}}=1.7,{ }^{3} \mathrm{~J}_{\mathrm{H}, \mathrm{Pt}}=10.2,1 \mathrm{H}\right.$, pz), $7.92\left(\mathrm{~d},{ }^{3} J_{\mathrm{H}, \mathrm{H}}=2.0,{ }^{3} J_{\mathrm{H}, \mathrm{Pt}}=10.3,1 \mathrm{H}, \mathrm{pz}\right), 7.67\left(\mathrm{dd},{ }^{3} J_{\mathrm{H} 9, \mathrm{H} 10}=8.2\right.$, $\left.{ }^{4} J_{\mathrm{H} 9, \mathrm{H} 7}=1.6,1 \mathrm{H}, \mathrm{H}_{9}\right), 7.52\left(\mathrm{~m},{ }^{3} J_{\mathrm{H}, \mathrm{Pt}}=44.0,1 \mathrm{H}, \mathrm{H}_{7}\right.$ partially overlapped with $\left.\mathrm{H}_{9}\right), 7.51\left(\mathrm{~m}, 1 \mathrm{H}, \mathrm{H}_{9}\right.$ partially overlapped with $\left.\mathrm{H}_{7}\right)$, $7.48\left(\mathrm{~d},{ }^{3} \mathrm{~J}_{\mathrm{H}, \mathrm{H}}=1.6,{ }^{3} \mathrm{~J}_{\mathrm{H}, \mathrm{Pt}}=40.0,1 \mathrm{H}, \mathrm{H}_{7}\right), 6.98\left(\mathrm{~d},{ }^{3} \mathrm{~J}_{\mathrm{H} 3, \mathrm{H} 2}=2.2,{ }^{4} J_{\mathrm{H}, \mathrm{Pt}}\right.$ $\left.=4.3,1 \mathrm{H}, \mathrm{H}_{2}\left(\mathrm{Pt}_{-} \mathrm{CHBr}_{2}\right)\right), 6.94\left(\mathrm{~d},{ }^{3} \mathrm{~J}_{\mathrm{H} 3, \mathrm{H} 2}=2.1,1 \mathrm{H}, \mathrm{H}_{2}(\mathrm{Pt}-\mathrm{Br})\right)$, 6.91-6.81 (m, 2H, $\left.\mathrm{H}_{10}\right), 6.43\left(\mathrm{t},{ }^{3} J_{\mathrm{H}, \mathrm{H}}=2.1,1 \mathrm{H}, \mathrm{H}_{4^{\prime}}, \mathrm{pz}\right), 6.40(\mathrm{t}$, $\left.{ }^{3} J_{\mathrm{H}, \mathrm{H}}=2.2,1 \mathrm{H}, \mathrm{H}_{4}, \mathrm{pz}\right), 6.35\left(\mathrm{~d},{ }^{3} J_{\mathrm{H} 3, \mathrm{H} 2}=2.2,{ }^{4} J_{\mathrm{H}, \mathrm{Pt}}=6.6,1 \mathrm{H}, \mathrm{H}_{3}\right.$ $(\mathrm{Pt}-\mathrm{CHBr} 2)), 6.23\left(\mathrm{~d},{ }^{3} J_{\mathrm{H} 3, \mathrm{H} 2}=2.1,{ }^{4} J_{\mathrm{H}, \mathrm{Pt}}=7.2,1 \mathrm{H}, \mathrm{H}_{3},(\mathrm{Pt}-\mathrm{Br})\right)$, $6.05\left(\mathrm{~s},{ }^{2} J_{\mathrm{Pt}, \mathrm{H}}=24.2,{ }^{3} J_{\mathrm{Pt}, \mathrm{H}}=6.3,1 \mathrm{H}, \mathrm{CHBr}\right), 4.38-4.22(\mathrm{~m}, 4 \mathrm{H}$, $\left.\mathrm{CH}_{2}, \mathrm{CO}_{2} \mathrm{Et}\right), 3.25$ (s, 3H, H$\left.{ }_{4}\left(\mathrm{Pt}-\mathrm{CHBr}_{2}\right)\right), 3.12\left(\mathrm{~s}, 3 \mathrm{H}, \mathrm{H}_{4}(\mathrm{Pt}-\right.$ $\mathrm{Br})), 1.34\left(\mathrm{t}, 6 \mathrm{H},{ }^{3} \mathrm{~J}_{\mathrm{H}, \mathrm{H}}=7.1, \mathrm{CH}_{3}\left(\mathrm{CO}_{2} \mathrm{Et}\right)\right) .{ }^{13} \mathrm{C}\left\{{ }^{1} \mathrm{H}\right\}$ NMR plus HMBC and HSQC (101 MHz, methylene chloride- $\left.d_{2}\right): \delta 166.7$ and 166.1 (s, 2C, $\mathrm{CO}_{2} \mathrm{Et}$ ), 152.1 (s, 1C, $\mathrm{C}_{1}$ (Pt-Br)), 148.7 (s, 1C, $\mathrm{C}_{1}$ (Pt$\left.\mathrm{CHBr}_{2}\right)$ ), 139.0, 137.4, 135.4, and $133.0(\mathrm{~s}, 4 \mathrm{C}, \mathrm{CH}, \mathrm{pz}), 133.8$ (s, $\left.1 \mathrm{C}, \mathrm{C}_{7}\right), 132.9$ (s, 1C, $\mathrm{C}_{7}$ ), 127.8 (s, 1C, $\mathrm{C}_{9}$ ), 126.6 (s, 1C, $\mathrm{C}_{9}$ ), 123.9 (s, 1C, $\left.\mathrm{C}_{3}\left(\mathrm{Pt}-\mathrm{CHBr}_{2}\right)\right), 122.8\left(\mathrm{~s}, 1 \mathrm{C}, \mathrm{C}_{3}(\mathrm{Pt}-\mathrm{Br})\right), 114.7$ (s, 1C, $\mathrm{C}_{2}$ $\left.\left(\mathrm{Pt}-\mathrm{CHBr}_{2}\right)\right), 114.4$ (s, 1C, $\left.\mathrm{C}_{2}(\mathrm{Pt}-\mathrm{Br})\right), 111.6\left(\mathrm{~s}, 1 \mathrm{C}, \mathrm{C}_{10}\right), 110.7$ (s, $\left.1 \mathrm{C}, \mathrm{C}_{10}\right), 106.1\left(\mathrm{~m}, 2 \mathrm{C}, \mathrm{C}_{4}\right), 61.6$ and $61.3\left(\mathrm{~s}, 2 \mathrm{C}, \mathrm{CH}_{2},\left(\mathrm{CO}_{2} \mathrm{Et}\right)\right)$, 37.2 and $37.0\left(\mathrm{~s}, 2 \mathrm{C}, \mathrm{C}_{4}\right), 14.7$ and $14.6\left(\mathrm{~s}, 2 \mathrm{C}, \mathrm{CH}_{3},\left(\mathrm{CO}_{2} \mathrm{Et}\right)\right)$. ${ }^{195} \mathrm{Pt}\left\{{ }^{1} \mathrm{H}\right\}$ NMR (85.6 MHz, methylene chloride- $\left.d_{2}\right): \delta-2443(\mathrm{~s}$, $\left.{ }^{1} J_{\mathrm{Pt}, \mathrm{Pt}}=1633 \mathrm{~Hz}, \mathrm{Pt}-\mathrm{CHBr}_{2}\right)$ and $-2799 \mathrm{ppm}$ (s, Pt-Br). MS (MALDI+): $m / z \quad 1062.0 \quad\left[\left\{\mathrm{Pt}\left(\mathrm{EtO}_{2} \mathrm{C}_{-} \mathrm{C}^{\wedge} \mathrm{C}^{*}\right)(\mu-\mathrm{pz})\right\}_{2} \mathrm{Br}\right], 1154.9$ $\left[\left\{\mathrm{Pt}\left(\mathrm{EtO}_{2} \mathrm{C}-\mathrm{C}^{\wedge} \mathrm{C}^{*}\right)(\mu-\mathrm{pz})\right\}_{2} \mathrm{CHBr}_{2}\right]$.

\section{RESULTS AND DISCUSSION}

Reactivity of 1 with Haloforms $\left(\mathrm{CHX}_{3}, \mathrm{X}=\mathrm{Br}, \mathrm{Cl}\right)$ : Synthesis and Characterization of New Metal-MetalBonded $\mathrm{Pt}_{2}(\mathrm{III}, \mathrm{III})$ Complexes. Compound $\mathbf{1}$ is thermally stable in $\mathrm{CHCl}_{3}$ solution in the air and in the dark at both room and reflux temperatures and also in refluxing toluene in the presence of $\mathrm{CHCl}_{3}(1 / 4)$ for at least $7 \mathrm{~h}$. However, the exposure of a solution of 1 (1/9 syn/anti ratio) in $\mathrm{CHCl}_{3}$ in the air to sunlight leads to its photochemical oxidation, rendering $\left.\left[\left\{\mathrm{Pt}\left(\mathrm{C}^{\wedge} \mathrm{C}^{*}\right)(\mu-\mathrm{pz}) \mathrm{Cl}\right)\right\}_{2}\right](\mathbf{2}-\mathrm{Cl})$. On the other hand, the reaction of 1 with $\mathrm{CHBr}_{3}(1 / 2.2)$ at room temperature in the air and sunlight rendered the complex $\mathrm{Pt}_{2}$ (III,III) $\mathrm{Br}_{2}$ (2-Br), but it surprisingly led to the compound $\left[\mathrm{BrPt}\left(\mathrm{C}^{\wedge} \mathrm{C}^{*}\right)(\mu-\mathrm{pz})_{2} \mathrm{Pt}\left(\mathrm{C}^{\wedge} \mathrm{C}^{*}\right) \mathrm{CHBr}_{2}\right](3-\mathrm{Br})$ in the dark under an argon atmosphere (see Figure 1, Scheme 1, and the Experimental Section).

Scheme 1. Reaction Pathways and Numbering Scheme for NMR Purposes ${ }^{a}$

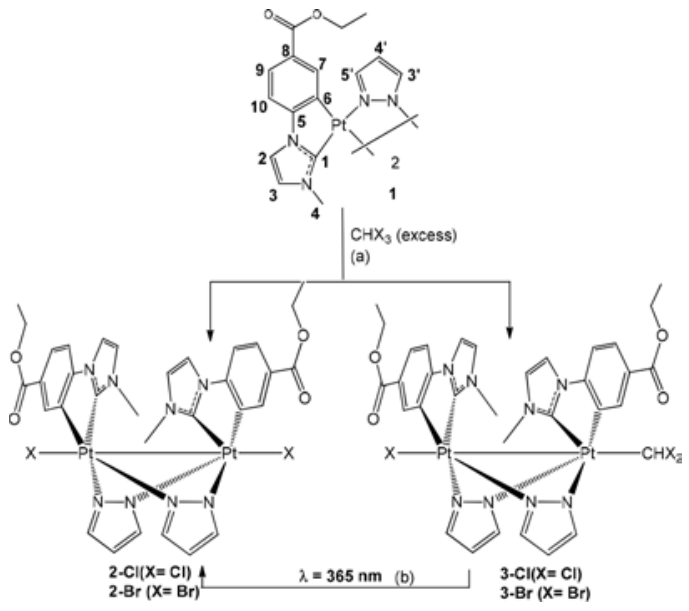

${ }^{a}$ For clarity, only the major isomer (anti) has been represented.
Compounds $\mathbf{2}-\mathbf{C l} / \mathbf{2}-\mathbf{B r}$ and $\mathbf{3}-\mathbf{B r}$ were isolated as yellow (2$\mathrm{Cl}, 3-\mathrm{Br}$ ) or orange (2-Br) solids in very good yields mostly as the anti isomer and then were fully characterized (see the Experimental Section, Figures 1 and 2, and Figures S1-S15 in the Supporting Information). However, compound $\mathbf{3 - C l}$ could be identified by ${ }^{1} \mathrm{H}$ and ${ }^{195} \mathrm{Pt}$ NMR from the reaction mixtures performed under an argon atmosphere (see Figures S16 and S17 in the Supporting Information). The higher oxidation state of $2-\mathrm{Cl} / \mathbf{2}-\mathrm{Br}$ and $3-\mathrm{Cl} / 3-\mathrm{Br}$ with respect to compound $\mathbf{1}$ can be inferred from the considerable reductions of the ${ }^{3} J_{\mathrm{Pt}, \mathrm{H} 7}$ coupling constants from $54 \mathrm{~Hz}$ in 1 to ca. $40 \mathrm{~Hz}^{26-28}$ and from the relevant downfield shifts $(\Delta \delta(\mathrm{Pt})=979-1337 \mathrm{ppm})$ of their ${ }^{195} \mathrm{Pt}$ NMR signals from $1\left(\delta\left({ }^{195} \mathrm{Pt}\right)=-3778 \mathrm{ppm}\right)$ (see Figures $\mathrm{S} 17$ and $\mathrm{S} 18$ in the Supporting Information). ${ }^{29}$ Structurally relevant for $\mathbf{3}-\mathbf{C l} / \mathbf{3}-\mathbf{B r}$ is the presence of two separated ${ }^{195} \mathrm{Pt}$ signals $\left({ }^{1} J_{\mathrm{Pt}, \mathrm{Pt}}=1633 \mathrm{~Hz}\right.$ for 3-Br), which evidence the existence of two nonequivalent $\mathrm{Pt}$ (III) fragments within these complexes (Figures S17 and S18 in the Supporting Information). In addition, the ${ }^{1} \mathrm{H}$ NMR spectra of $3-\mathrm{Cl} / 3-\mathrm{Br}$ show a singlet corresponding to the $\mathrm{Pt}-\mathrm{CHX}_{2}$ fragment $(6.59 \mathrm{ppm}, 3-\mathbf{C l} ; 6.05 \mathrm{ppm}, 3-\mathrm{Br})$, which in the case of 3-Br displays the expected ${ }^{195} \mathrm{Pt}$ satellite pattern in accord with its dinuclear $\mathrm{Pt}_{2}$ (III,III) formulation $\left({ }^{2} J_{\mathrm{Pt}, \mathrm{H}}=24.4 \mathrm{~Hz}\right.$, ${ }^{3} J_{\mathrm{Pt}, \mathrm{H}}=6.5 \mathrm{~Hz}$ ) (Figure 1).

These NMR features resembled those observed for [IPt$\left.\left(\mathrm{C}^{\wedge} \mathrm{C}^{*}\right)(\mu-\mathrm{pz})_{2} \mathrm{Pt}\left(\mathrm{C}^{\wedge} \mathrm{C}^{*}\right) \mathrm{CHI}_{2}\right]^{25}$ and $\left[\mathrm{Pt}_{2}(\mathrm{pop}){ }_{4} \mathrm{MeI}\right]\left({ }^{1} J_{\mathrm{Pt}, \mathrm{Pt}}\right.$ $=1550 \mathrm{~Hz}) .^{30}$

The molecular structures of $2-\mathbf{C l}, \mathbf{2 - B r}$, and $3-\mathbf{B r}$, determined by single-crystal X-ray crystallography (see Figure 2 and the Supporting Information for a full description) were quite similar to those of $\left.\left[\left\{\mathrm{Pt}\left(\mathrm{C}^{\wedge} \mathrm{C}^{*}\right)(\mu \text {-pz }) \mathrm{I}\right)\right\}_{2}\right]$ and $[\mathrm{IPt}$ $\left.\left(\mathrm{C}^{\wedge} \mathrm{C}^{*}\right)(\mu-\mathrm{pz})_{2} \mathrm{Pt}\left(\mathrm{C}^{\wedge} \mathrm{C}^{*}\right) \mathrm{CHI}_{2}\right]$, respectively. ${ }^{25}$ As far as we know, these are the only dinuclear metal-metal-bonded $\mathrm{Pt}^{\mathrm{III}}(\mu-\mathrm{pz})_{2} \mathrm{Pt}^{\mathrm{III}}$ compounds reported to date.

Experimental Data for the Mechanistic Study of the Reactivity of 1 with $\mathrm{CHX}_{3}(\mathrm{X}=\mathrm{Cl}, \mathrm{Br})$. The oxidation of 1 with $\mathrm{CHCl}_{3}$ requires light to occur, as is the case for most oxidations of $\mathrm{Pt}(\mathrm{II})$ complexes by chlorocarbons. ${ }^{7,31-33}$ The reaction mechanism was investigated by reacting $1\left(8 \times 10^{-3}\right.$ $\mathrm{M})$ with $\mathrm{CHCl}_{3}(1 / 5$ molar ratio $)$ in acetone- $d_{6}$ in NMR tubes under different conditions and following the reactions by ${ }^{1} \mathrm{H}$ NMR spectroscopy (see Scheme 1 and Table 1). Comparative experiments were performed simultaneously to avoid differences in the temperature. Two samples were prepared in the dark under an argon atmosphere, one of them with and the other without galvinoxyl $\left(\mathrm{Gal}^{\bullet}\right)$, and irradiated with a $365 \mathrm{~nm}$ UV lamp (see Figure S20). These experiments showed that $\mathrm{Gal}^{\bullet}$ slows down the reaction and allows the selective formation of the species $\mathbf{2 - C l}$, pointing to a radical mechanism, with $\mathrm{Gal}{ }^{\bullet}$ acting as a radical $\left(\mathrm{R}^{\bullet}\right)$ scavenger. ${ }^{30,33}$ The role of $\mathrm{O}_{2}$ as a radical trap in the reactions performed in the air was confirmed, since an aerated sample rendered $\mathbf{2 - C l}$ as the only oxidized species (see Figure S21) as well.

Additionally, we observed that in the air the reaction occurs by irradiation with blue LEDs $\left(\lambda_{\max }=457 \mathrm{~nm}\right)$, but not with green $\left(\lambda_{\max }=510 \mathrm{~nm}\right)$ or red $\left(\lambda_{\max }=631 \mathrm{~nm}\right)$ LEDs (see Figure S22), rendering 2-Cl as the unique $\mathrm{Pt}_{2}$ (III,III) species. In this case the reaction goes more quickly than that under 365 nm UV light (see Table 1, Figure S23, and Table S3 for more details). Moreover, aerated diluted solutions $\left(10^{-5} \mathrm{M}\right)$ of 1 in acetone- $d_{6}$ did not react with $\mathrm{CHCl}_{3}$ under blue LEDs but they did under $365 \mathrm{~nm}$ UV light to give 2-Cl (Figure S24). 


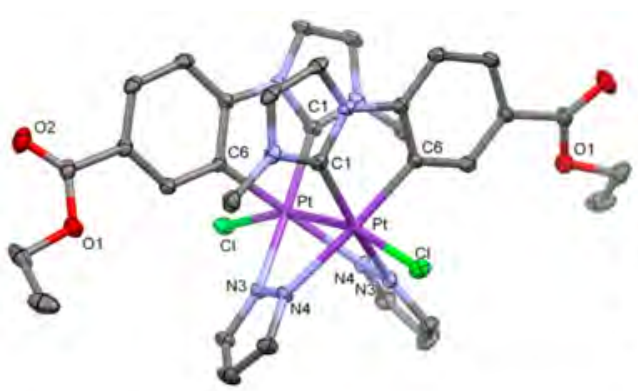

(a)

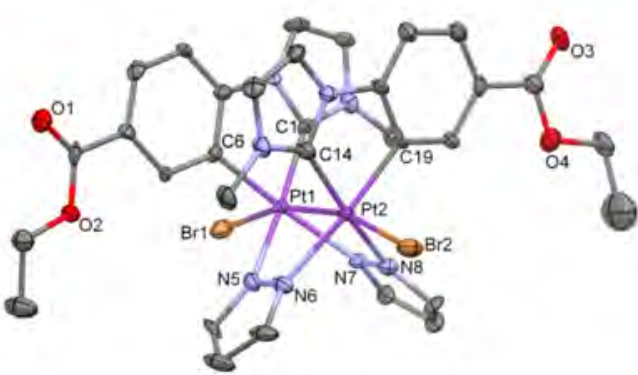

(b)

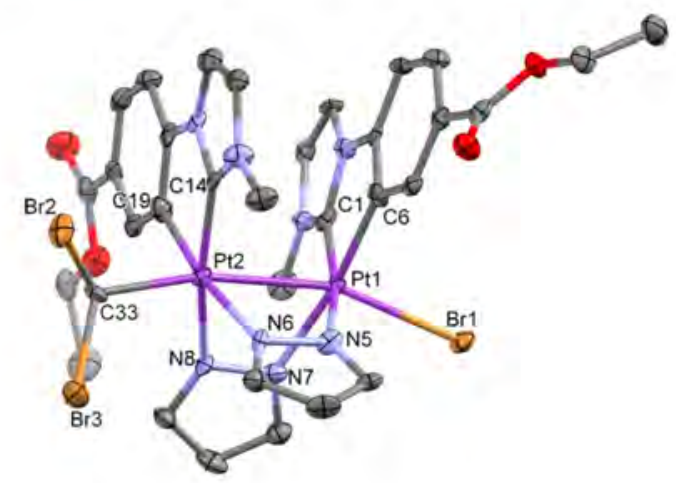

(c)

Figure 2. Molecular structures of complexes 2-Cl (a), 2-Br (b), and 3-Br (c). Ellipsoids are drawn at the 50\% probability level; solvent molecules and hydrogen atoms have been omitted for clarity. $d_{\mathrm{Pt}-\mathrm{Pt}}: 2.57446(18) \AA(2-\mathrm{Cl}), 2.5849(6) \AA$ (2-Br), 2.6302(4) $\AA$ (3-Br).

Table 1. Data Corresponding to the Reaction of $1\left(8 \times 10^{-3}\right.$ $\mathrm{M})$ with $\mathrm{CHX}_{3}(\mathrm{X}=\mathrm{Cl}, \mathrm{Br})$

\begin{tabular}{|c|c|c|c|c|c|}
\hline \multicolumn{3}{|c|}{$\mathrm{CHCl}_{3}$ ratio $(\%) \mathbf{1} / 2-\mathrm{Cl} / 3-\mathrm{Cl}$} & \multicolumn{3}{|c|}{$\mathrm{CHBr}_{3}$ ratio $(\%) \mathbf{1} / \mathbf{2}-\mathrm{Br} / 3-\mathrm{Br}$} \\
\hline $15 \mathrm{~min}$ & $8 \mathrm{~h}$ & $24 \mathrm{~h}$ & $15 \mathrm{~min}$ & $3.5 \mathrm{~h}$ & $24 \mathrm{~h}$ \\
\hline \multicolumn{3}{|c|}{$\mathrm{Ar} / \lambda=365 \mathrm{~nm}$} & \multicolumn{3}{|c|}{$\mathrm{Ar} / \mathrm{dark}$} \\
\hline $89 / 8 / 3$ & & $35 / 33 / 32$ & $0 / 0 / 100$ & $0 / 0 / 100$ & $0 / 0 / 100$ \\
\hline \multicolumn{3}{|c|}{$\mathrm{Ar} / \lambda=365 \mathrm{~nm}\left(\mathrm{Gal}^{*}\right)$} & \multicolumn{3}{|c|}{$\mathrm{Ar} /$ dark $\left(\mathrm{Gal}^{*}\right)$} \\
\hline $100 / 0 / 0$ & & $82 / 18 / 0$ & $100 / 0 / 0$ & $100 / 0 / 0$ & $100 / 0 / 0$ \\
\hline \multicolumn{3}{|c|}{ air $/ \lambda=365 \mathrm{~nm}$} & \multicolumn{3}{|c|}{ air/dark } \\
\hline $83 / 17 / 0$ & $34 / 66 / 0$ & $0 / 100 / 0$ & $86 / 9 / 5$ & $81 / 14 / 5$ & $74 / 18 / 8$ \\
\hline \multicolumn{3}{|c|}{ air/457 nm blue LEDs } & \multicolumn{3}{|c|}{ air/sunlight } \\
\hline $80 / 20 / 0$ & $8 / 92 / 0$ & $0 / 100 / 0$ & $0 / 71 / 29$ & $0 / 92 / 8$ & $0 / 100 / 0$ \\
\hline \multicolumn{6}{|c|}{ air/457 $\mathrm{nm}$ blue LEDs/anthracene } \\
\hline & $7 / 93 / 0$ & $0 / 100 / 0$ & & & \\
\hline
\end{tabular}

On the other hand, the reaction of a concentrated solution of $1\left(8 \times 10^{-3} \mathrm{M}\right)$ with oxygen-free $\mathrm{CHBr}_{3}(1 / 4$ molar ratio in acetone- $\left.d_{6}\right)$ in the dark under an Ar atmosphere is complete in $15 \mathrm{~min}$, to give selectively $3-\mathbf{B r}$ (syn/anti mixture), which remained unchanged under the experimental conditions for at least $24 \mathrm{~h}$. However, in the air, the reaction was less selective than that under $\mathrm{Ar}$, rendering mixtures of $\mathbf{2}-\mathbf{B r}$ and $3-\mathbf{B r}$ (see Scheme 1, Table 1, and Figure S25). These results pointed as well to a radical pathway for step a (Scheme 1), in which $\mathrm{O}_{2}$ acts as a radical $\left(R^{\bullet}\right)$ trap, increasing the amount of $2-\mathbf{B r}$ in the reaction mixture. In contrast, under the same ambient conditions a diluted solution $\left(10^{-4}-10^{-5} \mathrm{M}\right)$ of 1 did not react with $\mathrm{CHBr}_{3}$ even after $45 \mathrm{~h}$ (Figure S26), while it did under $365 \mathrm{~nm}$ UV light (Figure S27) in $45 \mathrm{~min}$ to render 2-Br.
Considering the selective formation of $3-\mathrm{Br}$ by reaction of 1 with $\mathrm{CHBr}_{3}$ under an $\mathrm{Ar}$ atmosphere in the dark and the fast and selective transformation of $\mathbf{1}$ into $\mathbf{2}-\mathbf{B r}$ when the reaction proceeds in the air and the sunlight (see the Experimental Section and Table 1), we investigated for the first time the role of both light and $\mathrm{O}_{2}$ in the transformation of 3-Br into $2-\mathbf{B r}$ (path $\mathrm{b}$ in Scheme 1). With that purpose, we prepared first two reaction experiments containing 3-Br (obtained from 1 and $\mathrm{CHBr}_{3}$ under argon in the dark) in J. Young NMR tubes. Subsequently, one of the samples was freeze-pump-thaw degassed and placed under an $\mathrm{O}_{2}$ atmosphere $(1 \mathrm{~atm})$. Then, both samples were irradiated with UV light $(\lambda=365 \mathrm{~nm})$ for 5 min, rendering $2-\mathbf{B r} / 3-\mathbf{B r}$ mixtures in different ratios $(28 \% /$ $72 \%$ in the oxygen-free sample and $64 \% / 36 \%$ in the oxygencontaining sample) (Figure S28). When it is kept in mind that under $\mathrm{Ar}$ in the dark compound 3-Br remained unchanged for at least $24 \mathrm{~h}$, the selective transformation of $3-\mathbf{B r}$ into $2-\mathbf{B r}$ is clearly promoted by UV light with $\mathrm{O}_{2}$ not being required but making the process faster. In a thorough analysis of the ${ }^{1} \mathrm{H}$ NMR spectra, it was possible to identify a singlet at $6.66 \mathrm{ppm}$ in the oxygen-free sample corresponding to 1,1,2,2-tetrabromoethane $\left(\mathrm{C}_{2} \mathrm{H}_{2} \mathrm{Br}_{4}\right)$ generated by $\mathrm{R}-\mathrm{R}$ coupling (Figure $\mathrm{S} 28$ ). To prove the radical mechanism of path $\mathrm{b}$, two samples containing 3-Br (obtained from 1 and $\mathrm{CHBr}_{3}, 1 / 4$ molar ratio, under argon in the dark) were prepared and then $\mathrm{Gal}^{\bullet}$ was added to one of them. After irradiation with a $365 \mathrm{~nm}$ UV light just the $\mathrm{Gal}^{\bullet}$-free sample showed the signal corresponding to 1,1,2,2-tetrabromoethane $\left(\mathrm{C}_{2} \mathrm{H}_{2} \mathrm{Br}_{4}\right)$ (Figure S29) and a faster transformation of 3-Br into 2-Br. Therefore, under an $\mathrm{Ar}$ atmosphere, the photochemical bond homolysis of the $\mathrm{Pt}-\mathrm{C}$ 

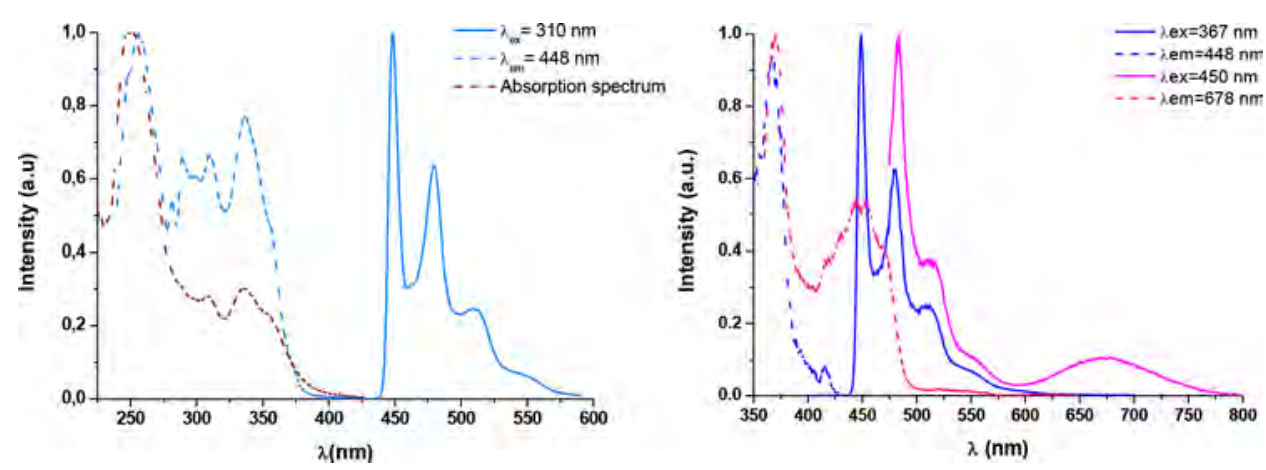

Figure 3. (left) Absorption spectrum (garnet dotted plot) of $\mathbf{1}$ in 2-MeTHF $\left(10^{-4} \mathrm{M}\right)$ at $\mathrm{rt}$ and the excitation (sky-blue dotted plot) and emission (blue solid plot) spectra of 1 in 2-MeTHF (under Ar, $10^{-5} \mathrm{M}$ ) at $77 \mathrm{~K}$. (right) Excitation (dotted plots) and emission (solid plots) spectra of 1 in 2-MeTHF $\left(10^{-3} \mathrm{M}\right)$ under $\mathrm{Ar}$ at $77 \mathrm{~K}$.

$\left(\mathrm{CHBr}_{2}\right)$ bond in 3-Br promoted by UV irradiation ${ }^{34}$ followed by $\mathrm{Br}$ abstraction from $\mathrm{CHBr}_{3}$ could account for the selective formation of 2-Br.

To shed light on the concentration-dependent reactivity of $\mathbf{1}$ with $\mathrm{CHX}_{3}(\mathrm{X}=\mathrm{Cl}, \mathrm{Br})$, we recorded the excitation and emission spectra for diluted $\left(10^{-5} \mathrm{M}\right)$ and concentrated $\left(10^{-3}\right.$ M) solutions of 1 in 2-MeTHF and explained them on the basis of theoretical calculations, as can be seen in the following.

Emission Spectra and Theoretical Calculations on Complex 1. The excitation and emission spectra of diluted $\left(10^{-5} \mathrm{M}\right)$ and concentrated $\left(10^{-3} \mathrm{M}\right)$ solutions of 1 in 2 MeTHF under an Ar atmosphere at $77 \mathrm{~K}$ can be seen in Figure 3. For a diluted solution of 1 (see Figure 3, left) just one excited state at high energy $\left(S_{1 s}, \lambda_{\max }=355 \mathrm{~nm}\right.$, tail to $380 \mathrm{~nm}$; $\mathrm{T}_{1 \mathrm{~s}}, \lambda_{\max }=450 \mathrm{~nm}$ ) is perceptible, which can be reached by irradiation with a $365 \mathrm{~nm}$ UV light. In a concentrated solution of 1 (see Figure 3, right), an additional excited state at low energy appears $\left(S_{1 f}, \lambda_{\max }=450 \mathrm{~nm} ; T_{1 f}, \lambda_{\max }=678 \mathrm{~nm}\right)$ by irradiation in the range $450-470 \mathrm{~nm}$.

In view of the experimental results and taking into account the different Pt...Pt distances observed for complex 1 (three independent molecules in the asymmetric unit with $\mathrm{Pt}-\mathrm{Pt}$ separations of 3.1210(3), 3.2294(4), and 3.2834(4) $\AA$ were found in a single-crystal X-ray diffraction study of 1$)^{25}$ we studied the potential energy surface (PES) of the $S_{0}$ model complex 1-DFT in acetone solution as a function of the $\mathrm{Pt}-\mathrm{Pt}$ distance. Interestingly we found two stationary points (see Figure 4), characterized as local minima showing quite different geometries: a butterfly-spreading structure, 1-s, and a butterfly-folding structure, 1-f (Figure 4). 1-s shows a long $\mathrm{Pt}-\mathrm{Pt}$ distance of $3.212 \AA$ and long intramolecular $\mathrm{C}-\mathrm{C}$ distances between the $C^{\wedge} C^{*}$ groups in the wings $(d \geq 4.83 \AA)$. Conversely, 1-f shows a short Pt-Pt distance of $2.98 \AA$ and short intramolecular $\mathrm{C}-\mathrm{C}$ contacts between the $\mathrm{C}^{\wedge} \mathrm{C}^{*}$ groups in the wings (3.624-3.843 $\AA$ ). Both structures are very close in energy in the PES $\left(\Delta G^{\circ}=1.7 \mathrm{kcal} / \mathrm{mol}\right)$. Furthermore, we have located a transition state, connecting both structures, with one negative frequency associated with the butterfly-spreading, butterfly-folding intramolecular dynamics. The transition state connecting both minima presents intermediate parameters, with a Pt-Pt distance of $3.012 \AA$ and long intramolecular C-C contacts between the $\mathrm{C}^{\wedge} \mathrm{C}^{*}$ groups $(d \geq 3.93 \AA)$, and lies only $1.9 \mathrm{kcal} / \mathrm{mol}$ above $1-\mathrm{s}$ and $0.2 \mathrm{kcal} / \mathrm{mol}$ above 1 -f. These very low barriers support a fast thermally induced structural change in the ground state, likely through a dynamics resembling an intramolecular butterfly flapping, and are fully consistent with the presence of both conformations of $\mathbf{1}$ in acetone solution.

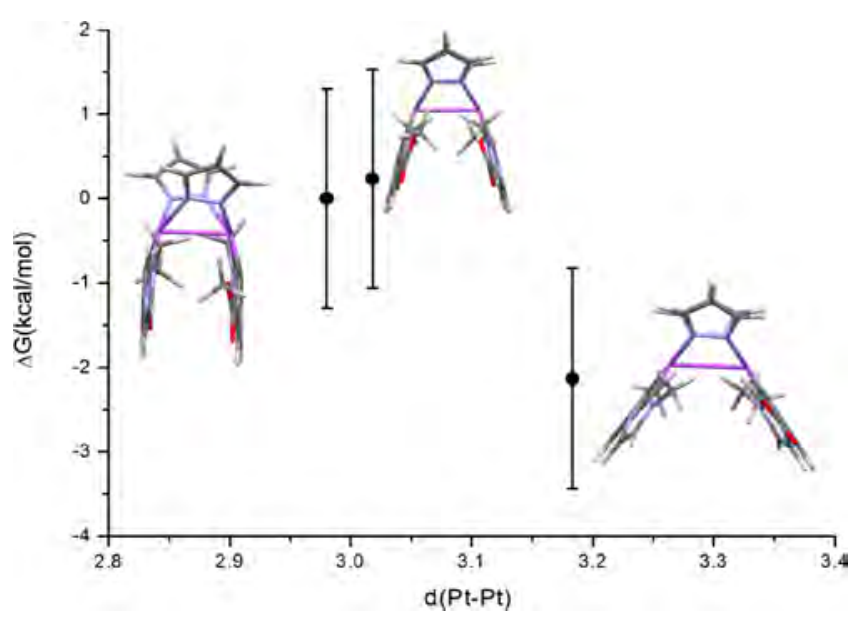

Figure 4. Calculated energy profile for the butterfly-spreadingbutterfly-folding structures (1-s and 1-f) interconversion of the $S_{0}$ state of the dinuclear complex 1-DFT in acetone, including the transition state $(\mathrm{Ts})$. MUE $(\mathrm{M} 06)=2.48 \mathrm{kcal} / \mathrm{mol} \cdot{ }^{35}$

The calculated $S_{1 \mathrm{~s}}$ value $(367 \mathrm{~nm})$ of the butterfly wingspreading structure 1-s mostly corresponds to the HOMOLUMO transition (93\%) at the $\mathrm{S}_{0}$ geometry (see Tables S4 and S5 and Figure S30). In view of the population analysis (\%) of the frontier molecular orbitals (FMOs), $S_{1 s}$ is ${ }^{1} \mathrm{LC} /{ }^{1} \mathrm{MLCT}$ in nature. We also optimized the lowest triplet state of 1-s $\left(\mathrm{T}_{1 \mathrm{~s}}\right)$ in acetone solution (see Figure 5). It showed a Pt-Pt distance $(3.178 \AA$ ) and a $\mathrm{Pt}-\mathrm{Pt}$ bond order $(0.11)$ quite similar to those $(3.212 \AA, 0.10)$ in the ground state $\left(\mathrm{S}_{0 \mathrm{~s}}\right)$. Furthermore, both the spin density distribution (see Figure 5) and the calculated energy $\left(\Delta E_{\mathrm{T} 1 \mathrm{~s}-S 0 \mathrm{~s}}=2.738 \mathrm{eV}, 453 \mathrm{~nm}\right)$ for $\mathrm{T}_{1 \mathrm{~s}}$ support its ${ }^{3} \mathrm{IL} /{ }^{3} \mathrm{MLCT}$ nature, indicating 1-s molecules are responsible for the high-energy absorption/emission $\left(\mathrm{S}_{1 \mathrm{~s}}\right.$, $\lambda_{\max }=355 \mathrm{~nm}$, tail to $380 \mathrm{~nm} ; \mathrm{T}_{1 s}, \lambda_{\max }=450 \mathrm{~nm}$ ) bands observed for solutions of $\mathbf{1}$ in 2-MeTHF.

In addition, we optimized the ground $\left(\mathrm{S}_{0 \mathrm{f}}\right)$ and the lowest triplet $\left(\mathrm{T}_{1 \mathrm{f}}\right)$ states of the butterfly wing-folded structure, $\mathbf{1}-\mathbf{f}$, in acetone solution (see Figure 5 and the Supporting Information). Unlike $\mathrm{T}_{1 \mathrm{~s}}, \mathrm{~T}_{1 \mathrm{f}}$ showed a $\mathrm{Pt}-\mathrm{Pt}$ distance of $2.746 \AA$, clearly shorter than that in the ground state $S_{0 f}, 2.98$ $\AA$, in agreement with the increased bonding character between the metal centers $\left(\mathrm{BO}=0.62\left(\mathrm{~T}_{1 \mathrm{f}}\right), 0.22\left(\mathrm{~S}_{\text {of }}\right)\right)$. These two parameters and the spin density distribution calculated for $\mathrm{T}_{1 \mathrm{f}}$ (Figure 5) are in accordance with a mainly ${ }^{1 / 3} \mathrm{MMLCT}$ $\left(\mathrm{d} \sigma^{*}(\mathrm{Pt}-\mathrm{Pt}) \rightarrow \pi^{*}\left(\mathrm{C}^{\wedge} \mathrm{C}^{*}\right)\right)$ nature of the lower energy excited states of species 1-f (see Tables S4 and S5, Figure 5, 


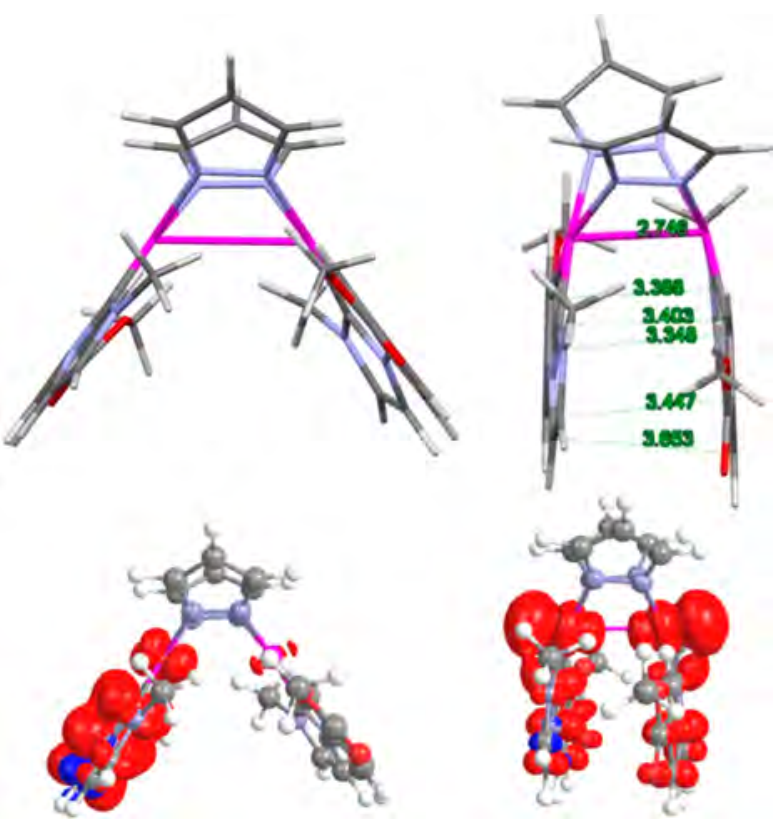

Figure 5. (top) Calculated structures in acetone solutions of $\mathrm{T}_{1 \mathrm{~s}}$ (left) and $\mathrm{T}_{1 \mathrm{f}}$ (right): (bottom) Spin density distribution for $\mathrm{T}_{1 \mathrm{~s}}$ (left) and $\mathrm{T}_{1 \mathrm{f}}$ (right).

and Figure S30). This is due to the interactions through the $d_{z^{2}}$ orbital of the two platinum atoms located in close proximity and will be somehow affected by the intramolecular $\pi-\pi$ interactions. These results agree with the ${ }^{1 / 3}$ MMLCT excited states of $1-f$ to be the origin of the low-energy excitation $\left(\lambda_{\max }\right.$ $=450 \mathrm{~nm})$ and emission $\left(\lambda_{\max }=678 \mathrm{~nm}\right)$ bands observed for concentrated solutions of $\mathbf{1}$ in 2-MeTHF.

The possibility of low-lying excited states due to intermolecular $\pi-\pi$ interactions was ruled out, since the lowenergy excitation and emission bands of 1 in concentrated $\left(10^{-3} \mathrm{M}\right)$ solutions (Figure S31, bottom) differ from those in the solid state, where extensive intermolecular $\pi-\pi$ interactions are expected (see the X-ray molecular packing of $\mathbf{1}$ in Figure S31, top). Thus, it leads us to consider the low-energy excitation and emission bands observed for concentrated $\left(10^{-3}\right.$ M) solutions of 1 are most likely due to the ${ }^{1 / 3}$ MMLCT excited states of $\mathbf{1 - f}$ rather than to aggregates. The coexistence of molecules with short and long intramolecular $\mathrm{Pt}-\mathrm{Pt}$ distances was proposed by Thompson to explain the EL for devices using $\left[\left\{\mathrm{Pt}\left(\mathrm{C}^{\wedge} \mathrm{N}\right)(\mu-\mathrm{pz})\right\}_{2}\right] \quad\left(\mathrm{C}^{\wedge} \mathrm{N}=2-\left(4^{\prime}, 6^{\prime}-\right.\right.$ difluorophenyl)pyridinato- $N, \mathrm{C}^{2}, \mathrm{pz}=$ pyrazolate) as the dopant in high concentration $(70 \mathrm{wt} \%)$ or as a neat film. ${ }^{17}$

Then, our excitation/emission spectra and theoretical calculations pointed to the existence of both kinds of molecules, 1-s and 1-f, in acetone solutions. However, the $\Delta G$ value $\left(\Delta G_{1-\mathrm{f}}-\Delta G_{1-\mathrm{s}}=1.7 \mathrm{kcal} / \mathrm{mol}\right)$ for the $1-\mathbf{s} \leftrightarrow 1-\mathbf{f}$ transformation predicts a 1-f ratio of $6 \%$ at $298 \mathrm{~K}$, being much lower as the temperature is decreased. ${ }^{36}$ At $77 \mathrm{~K}$ the 1-f ratio seems to be as low, as in diluted solutions of $\mathbf{1}$ the low-energy emission of 1-f is undetectable but can be detected in more concentrated solutions (Figure 3).

In addition, considering the $[2 \mathrm{c}, 2 \mathrm{e}]$ oxidation of the butterfly $\mathrm{Pt}_{2}(\mathrm{II}, \mathrm{II})$ complexes $\left[\left\{\mathrm{Pt}\left(\mathrm{C}^{\wedge} \mathrm{N}\right)(\mu \text {-pz })\right\}_{2}\right]$, by haloforms $\left(\mathrm{CHX}_{3}, \mathrm{X}=\mathrm{Cl}, \mathrm{Br}, \mathrm{I}\right)$ had been never described, we performed the NBO charge distributions analysis on both the compound $\left[\left\{\mathrm{Pt}\left(\mathrm{C}^{\wedge} \mathrm{C}^{*}\right)(\mu-\mathrm{pz})\right\}_{2}\right]$ (1) and the analogous $\left[\left\{\operatorname{Pt}\left(\mathrm{C}^{\wedge} \mathrm{N}\right)(\mu-\mathrm{pz})\right\}_{2}\right] \quad\left(\mathrm{C}^{\wedge} \mathrm{N}=2\right.$-phenylpyridinate $)$ at the
DFT/M06/SDD/6-31G* level of theory in acetone solution. These calculations showed the atomic charges on the platinum centers of 1 to be +0.273 (1-f) and +0.288 (1-s) while those on the platinum centers of $\left[\left\{\mathrm{Pt}\left(\mathrm{C}^{\wedge} \mathrm{N}\right)(\mu-\mathrm{pz})\right\}_{2}\right]$ are +0.407 . The lower value observed in the $\mathrm{C}^{\wedge} \mathrm{C}^{*}$ derivative is attributable to the greater donor ability of $\mathrm{C}^{\wedge} \mathrm{C}^{*}$ with respect to $\mathrm{C}^{\wedge} \mathrm{N}^{37}$ and could contribute to the easier oxidation of this butterfly compound, 1.

Discussion of the Reactivity of 1 with $\mathrm{CHX}_{3}(\mathrm{X}=\mathrm{Cl}$, $\mathrm{Br})$. The results showed above indicated that diluted solutions of $1\left(10^{-5}, 10^{-4} \mathrm{M}\right)$ react with $\mathrm{CHX}_{3}(\mathrm{X}=\mathrm{Cl}, \mathrm{Br})$ under 365 $\mathrm{nm}$ UV light, but at higher concentrations of $\mathbf{1}\left(8 \times 10^{-3} \mathrm{M}\right)$ in acetone, the reaction can be initiated by heat $(\mathrm{X}=\mathrm{Br})$ or blue light $\left(\mathrm{X}=\mathrm{Cl}, \lambda_{\mathrm{exc}} \approx 460 \mathrm{~nm}\right)$, following a radical process (path a in Scheme 1) to render species 2, 3, or a mixture of both, depending on the ambient conditions. In addition, under UV light species 3 convertd into 2 following a radical pathway (path $\mathbf{b}$ in Scheme 1) as well, which explains how in ambient light $\mathbf{1}$ converts completely into $\mathbf{2}-\mathbf{C l} / \mathbf{2}-\mathbf{B r}$ in the presence of excess $\mathrm{CHX}_{3}(\mathrm{X}=\mathrm{Cl}, \mathrm{Br})$.

Since the reaction of 1 with $\mathrm{CHCl}_{3}$ is driven by $365 \mathrm{~nm} \mathrm{UV}$ light $\left([1]=10^{-5} \mathrm{M}\right)$ or blue light $\left([1]=8 \times 10^{-3} \mathrm{M}\right)$, a haloform-initiated radical pathway ${ }^{38}$ can be excluded. Instead, the reaction should be initiated by platinum-based excited species, generated by irradiation of complex $\mathbf{1}$. Thus, under the experimental conditions, when a concentrated sample of $\mathbf{1}$ (8 $\times 10^{-3} \mathrm{M}$ solution in acetone- $\left.d_{6}\right)$ was irradiated with blue LEDs $\left(\lambda_{\max }=457 \mathrm{~nm}\right)$ the ${ }^{1}$ MMLCT of species 1-f $\left(S_{1 f}\right)$ was reached (Scheme 2) and then the ${ }^{1}$ MMLCT or ${ }^{3}$ MMLCT

Scheme 2. Schematic Diagram of Energy Levels for the Ground and Excited States: Photophysical Processes Based on the Steady-State Excitation and Emission Spectra along with Theoretical Calculations

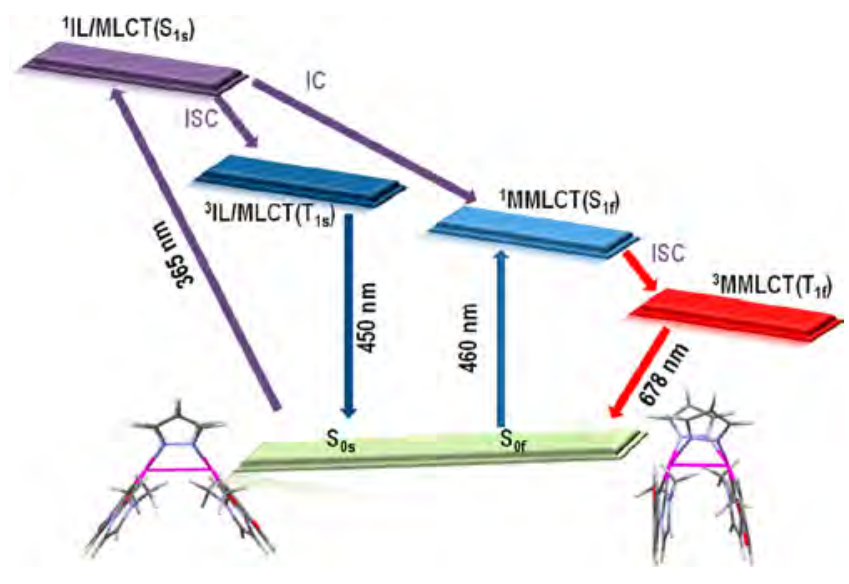

(reached by an ISC process) excited states would likely initiate the fast reaction with $\mathrm{CHCl}_{3}$. To discern between the singlet/ triplet nature of the reactive $[1-\mathrm{f}] *$ species, we used anthracene as a quencher of the triplet excited states $\left(\mathrm{E}_{\mathrm{S}}<350 \mathrm{~nm}, E_{\mathrm{T}}=\right.$ $681 \mathrm{~nm}))^{39}$ For that, two samples $\left(8 \times 10^{-3} \mathrm{M} 1\right.$ and $\mathrm{CHCl}_{3}$, $1 / 5)$ were prepared in the air under blue LEDs, one of them with and the other one without anthracene $(0.08 \mathrm{M})$.

In both samples, the exciting light $\left(\lambda_{\max }=457 \mathrm{~nm}\right)$ must be completely absorbed by complex 1 . By ${ }^{1} \mathrm{H}$ NMR we observed that after 2,6 , and $8 \mathrm{~h}$ the unreacted amounts of 1 were ca. $51 \%, 16 \%$, and $8 \%$, respectively, in both samples, with no visible differences between them (Table 1 and Table S3). On 
Scheme 3. Comparative DFT-Calculated Pathways and Energy Barriers $(\Delta G, \mathrm{kcal} / \mathrm{mol})$ for the Thermal Conversion of $1\left(S_{0 \mathrm{~s}}\right)$ into $2-\mathrm{Cl} / \mathrm{Br}$ and $3-\mathrm{Cl} / \mathrm{Br}$ following a $\mathrm{S}_{\mathrm{N}} 2$ (i) or a Radical Mechanism (ii) ${ }^{a}$

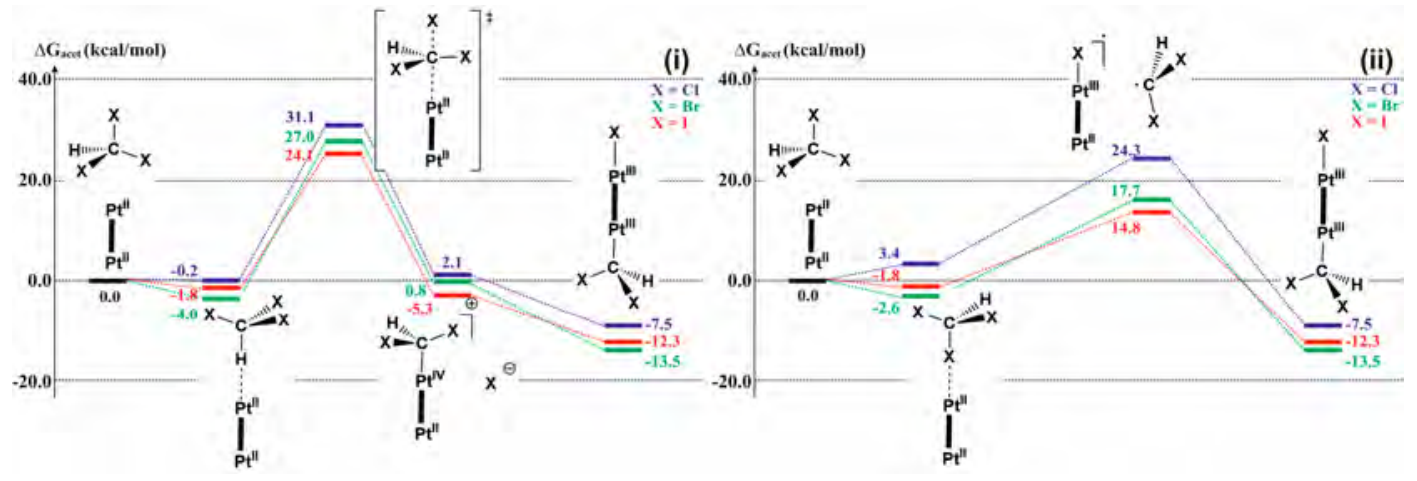

${ }^{a_{T}}$ The values corresponding to the reaction of 1 with $\mathrm{CHI}_{3}$ have been included for an overall picture of these reactions. MUE (M06) $=2.48 \mathrm{kcal} /$ mol.

the other hand, we observed that the presence of anthracene quenches the ${ }^{3} \mathrm{MMLCT}$ phosphorescence of 1 upon excitation at $460 \mathrm{~nm}$ (Figure S32). Since anthracene quenches the ${ }^{3} \mathrm{MMLCT}$ phosphorescence of $\mathbf{1}$ but not its photoreaction with $\mathrm{CHCl}_{3},{ }^{1}[\mathbf{1 - f}]^{*}$ species, ${ }^{1} \mathrm{MMLCT}$ in nature, seems to be the reactive species (Scheme 2). These results agree with the observed effect of $\mathrm{O}_{2}\left(E_{\mathrm{T} 1}=1192 \mathrm{~nm}, E_{\mathrm{T} 2}=773 \mathrm{~nm}\right)$ quenching the phosphorescence of 1 (see Figure S33) upon excitation at $400 \mathrm{~nm}$ but not the photoreaction with $\mathrm{CHCl}_{3}$ (see Table 1 and Scheme 1). Thus, under blue light, the species ${ }^{1}[\mathbf{1 - f}]^{*}$ would interact with $\mathrm{CHCl}_{3}$, undergoing dissociation into $\mathrm{Pt}_{2} \mathrm{Cl}^{\bullet}$ and $\mathrm{CHCl}_{2}{ }^{\bullet}$, as the first step of the radical reaction.

At high concentration $\left(8 \times 10^{-3} \mathrm{M}\right)$ in acetone under a 365 $\mathrm{nm}$ UV light the photooxidation rate of $\mathbf{1}$ is lower than that under blue light. In this case, irradiation will lead to the highenergy ${ }^{1} \mathrm{IL} / \mathrm{MLCT}$ excited state. Then, by ISC or IC the ${ }^{1} \mathrm{IL} /$ MLCT state can populate the ${ }^{3} \mathrm{IL} / \mathrm{MLCT}$ or ${ }^{1}$ MMLCT excited state, respectively, since the last two lie very close in energy (Scheme 2). If ${ }^{1}$ MMLCT corresponding to 1-f species are those that induce the reaction and are just partially populated, this would account for the slower oxidation observed under $365 \mathrm{~nm}$ UV light (see Scheme 2) with respect to the blue-lightdriven reaction.

On the other hand, the thermal oxidation of 1 with $\mathrm{CHBr}_{3}$ takes place in a concentrated solution of $1\left(8 \times 10^{-3} \mathrm{M}\right)$ in acetone but not in diluted solution $\left(10^{-4} \mathrm{M}\right)$ even after $45 \mathrm{~h}$, presumably because in concentrated solutions of 1 the MMLCT-based species [1-f] will initiate a thermal radical process, while the almost negligible presence of such species in diluted solutions slows down the thermal reaction dramatically, in such a way that after $45 \mathrm{~h}$ no reaction was observed.

Theoretical calculations confirmed that a radical pathway through the homolytic breakage of the $\mathrm{Br}-\mathrm{C}$ bond in a $\mathrm{S}_{0}$ $\left[\mathrm{Pt}-\mathrm{Pt}-\mathrm{BrCHBr}_{2}\right]$ adduct is clearly the most favored option, among the proposed ones, for the thermal oxidation of $\mathbf{1}$ (see Scheme S1, path ii, and Scheme 3).

Furthermore, the concomitant generation of $\mathrm{Pt}_{2} \mathrm{Br}^{\bullet}$ and - $\mathrm{CHBr}_{2}\left(\mathrm{R}^{\bullet}\right)$ radicals is consistent with the simultaneous formation of $\mathrm{Pt}_{2} \mathrm{Br}_{2}$ (2-Br) and $\mathrm{Pt}_{2} \mathrm{Br}\left(\mathrm{CHBr}_{2}\right)$ (3-Br) species (eqs $1-4)$. The role of $\mathrm{O}_{2}$ as a radical $\left(\mathrm{R}^{\bullet}\right)$ trap can justify the greater amount of $\mathbf{2 - B r}$ in the reaction mixture when the reaction is performed in the air with respect to that performed under an argon atmosphere.

$$
\begin{aligned}
& \mathrm{Pt}_{2}+\mathrm{RBr} \rightarrow \mathrm{Pt}_{2} \mathrm{Br}^{\bullet}+\mathrm{R}^{\bullet} \\
& \mathrm{Pt}_{2}+\mathrm{R}^{\bullet} \rightarrow \mathrm{Pt}_{2} \mathrm{R}^{\bullet} \\
& \mathrm{Pt}_{2} \mathrm{Br}^{\bullet}+\mathrm{RBr} \rightarrow \mathrm{Pt}_{2} \mathrm{Br}_{2}+\mathrm{R}^{\bullet} \\
& \mathrm{Pt}_{2} \mathrm{R}^{\bullet}+\mathrm{RBr} \rightarrow \mathrm{Pt}_{2} \mathrm{RBr}+\mathrm{R}^{\bullet}
\end{aligned}
$$

DFT calculations show a gradation for the $\mathrm{X}$ transfer process (Scheme 3ii), which is increasingly favored with the heavier haloforms. Whereas the calculated barrier for the reaction with $\mathrm{CHI}_{3}$ supports an easy process happening under a wide diversity of conditions, the barrier for the reaction with $\mathrm{CHBr}_{3}$ seems high enough as to be sensitive to other kinetic factors such as the concentration of reagents, in good agreement with experimentally observed trends. Finally, the reaction with chloroform shows the highest barrier and experimentally does not occur under thermal conditions. In this case, the $S_{1 f}$ species, reached by irradiation, will trigger the photooxidation of 1 with $\mathrm{CHCl}_{3}$ to give $\mathrm{Pt}_{2}$ (III,III) complexes following a radical mechanism.

\section{CONCLUSION}

This paper shows the $[2 c, 2 e]$ oxidation of the butterfly complex $\left[\left\{\mathrm{Pt}\left(\mathrm{C}^{\wedge} \mathrm{C}^{*}\right)(\mu-\mathrm{pz})\right\}_{2}\right](\mathbf{1})$ by $\mathrm{CHX}_{3}(\mathrm{X}=\mathrm{Cl}, \mathrm{Br})$ in acetone solution, which under controlled ambient conditions leads to the selective synthesis of the compounds $\left[\left\{\mathrm{Pt}\left(\mathrm{C}^{\wedge} \mathrm{C}^{*}\right)\right.\right.$ $\left.(\mu-\mathrm{pz}) \mathrm{X}\}_{2}\right](\mathrm{X}=\mathrm{Cl}(2-\mathrm{Cl}), \mathrm{Br}(2-\mathrm{Br}))$ and $\left[\mathrm{Pt}_{2}\left(\mathrm{C}^{\wedge} \mathrm{C}^{*}\right)_{2}(\mu\right.$ $\left.\mathrm{pz})_{2} \mathrm{Br}\left(\mathrm{CHBr}_{2}\right)\right]$ (3-Br). Together with the analogous iodo derivatives $\left.\left[\left\{\mathrm{Pt}\left(\mathrm{C}^{\wedge} \mathrm{C}^{*}\right)(\mu \text {-pz }) \mathrm{I}\right)\right\}_{2}\right]$ and $\left[\operatorname{IPt}\left(\mathrm{C}^{\wedge} \mathrm{C}^{*}\right)(\mu \text {-pz })_{2} \mathrm{Pt}\right.$ $\left.\left(\mathrm{C}^{\wedge} \mathrm{C}^{*}\right) \mathrm{CHI}_{2}\right]$, they are the only dinuclear metal-metalbonded $\mathrm{Pt}^{\mathrm{III}}(\mu-\mathrm{pz})_{2} \mathrm{Pt}^{\mathrm{III}}$ compounds reported to date.

The oxidation of 1 by $\mathrm{CHX}_{3}(\mathrm{X}=\mathrm{Cl}, \mathrm{Br})$ under UV light takes place in either diluted $\left(10^{-5} \mathrm{M}\right)$ or concentrated $(8 \times$ $10^{-3} \mathrm{M}$ ) solutions of $\mathbf{1}$ in acetone to give compounds $2-\mathbf{C l} / \mathbf{2}$ $\mathrm{Br}$. However, in concentrated solutions the oxidation of $\mathbf{1}$ is possible in the dark $\left(\mathrm{CHBr}_{3}\right)$ or under blue-light $\left(\mathrm{CHCl}_{3}\right)$ irradiation. Our theoretical results show the existence of two minima in the PES of the ground state $\left(S_{0}\right)$ of the model 1DFT in acetone solution: the butterfly wing-spreading molecules 1-s and the wing-folding molecules 1-f. They are very close in energy $\left(\Delta G^{\circ}=1.7 \mathrm{kcal} / \mathrm{mol}\right)$ and are connected through a low barrier transition state (TS), which supports a fast interconversion process resembling an intramolecular butterfly flapping and the presence of both kinds of molecules 
in acetone solution. The experimental results point to a radical mechanism, with the MMLCT-based 1-f species being those which trigger the heat- or blue-light-driven photooxidation of $\mathbf{1}$ with $\mathrm{CHBr}_{3}$ and $\mathrm{CHCl}_{3}$, respectively. The $\mathrm{C}^{\wedge} \mathrm{C}^{*}$ basicity and the cooperative effects between the two adjacent metal centers located in close proximity in the 1-f species appear to be crucial in promoting the homolytic $\mathrm{C}-\mathrm{X}(\mathrm{X}=\mathrm{Cl}, \mathrm{Br})$ bond breaking, which constitutes the first step of the radical mechanism of the oxidation of 1 by $\mathrm{CHX}_{3}(\mathrm{X}=\mathrm{Cl}, \mathrm{Br})$.

\section{ASSOCIATED CONTENT}

\section{SI Supporting Information}

The Supporting Information is available free of charge at https://pubs.acs.org/doi/10.1021/acs.inorgchem.0c01701.

Experimental details of the general procedures and instrumentation, crystallographic data, and computational methods, NMR spectra for characterization and mechanistic studies, single-crystal X-ray structures and description, emission spectra and theoretical calculations, and additional figures as described in the text (PDF)

\section{Accession Codes}

CCDC 1985166-1985168 contain the supplementary crystallographic data for this paper. These data can be obtained free of charge via www.ccdc.cam.ac.uk/data_request/cif, or by emailing data_request@ccdc.cam.ac.uk, or by contacting The Cambridge Crystallographic Data Centre, 12 Union Road, Cambridge CB2 1EZ, UK; fax: +44 1223336033.

\section{AUTHOR INFORMATION}

\section{Corresponding Authors}

Violeta Sicilia - Departamento de Quimica Inorgánica, Escuela de Ingenieria y Arquitectura de Zaragoza, Instituto de Sintesis Quimica y Catálisis Homogénea (ISQCH), CSIC-Universidad de Zaragoza, 50018 Zaragoza, Spain; ○ orcid.org/00000002-0257-0483; Email: sicilia@unizar.es

Sara Fuertes - Departamento de Quimica Inorgánica, Facultad de Ciencias, Instituto de Sintesis Quimica y Catálisis Homogénea (ISQCH), CSIC-Universidad de Zaragoza, 50009 Zaragoza, Spain; 이이.org/0000-0003-1812-3175; Email: sfuertes@unizar.es

\section{Authors}

Lorenzo Arnal - Departamento de Quimica Inorgánica, Facultad de Ciencias, Instituto de Sintesis Quimica y Catálisis Homogénea (ISQCH), CSIC-Universidad de Zaragoza, 50009 Zaragoza, Spain; 이이.org/0000-0002-0283-9307

Antonio Martín - Departamento de Quimica Inorgánica, Facultad de Ciencias, Instituto de Sintesis Quimica y Catálisis Homogénea (ISQCH), CSIC-Universidad de Zaragoza, 50009 Zaragoza, Spain; ○ orcid.org/0000-0002-4808-574X

Miguel Baya - Departamento de Quimica Inorgánica, Facultad de Ciencias, Instituto de Sintesis Quimica y Catálisis Homogénea (ISQCH), CSIC-Universidad de Zaragoza, 50009 Zaragoza, Spain; (1) orcid.org/0000-0002-2492-625X

Complete contact information is available at: https://pubs.acs.org/10.1021/acs.inorgchem.0c01701

\section{Notes}

The authors declare no competing financial interest.

\section{ACKNOWLEDGMENTS}

This work was supported by the Spanish Ministerio de Economía y Competitividad (Ministerio de Ciencia Innovación y Universidades)/FEDER (Project PGC2018-094749-BI00), the Gobierno de Aragón (Grupo E17_20R: Quimica Inorgánica y de los Compuestos Organometálicos), and FEDER 2014-2020 (Construyendo Europa desde Aragón). The authors thank the Instituto de Biocomputación y Física de Sistemas Complejos (BIFI) and Centro de Supercomputación de Galicia (CESGA) for generous allocation of computational resources. The authors thank Dr. M. V. Collados, at the University of Zaragoza for spectra of the LEDs used in this work and Prof. Daniel Escudero at the KU Leuven for its guidance with theoretical calculations. L.A. acknowledges the support of a grant from the Gobierno de Aragón. S.F. thanks the Spanish National Research Council for Grant No. 2018801070-PIE-147.

\section{REFERENCES}

(1) Powers, I. G.; Uyeda, C. Metal-Metal Bonds in Catalysis. ACS Catal. 2017, 7, 936-958.

(2) Powers, D. C.; Ritter, T. Bimetallic Pd(III) Complexes in Palladium-Catalysed Carbon-Heteroatom Bond Formation. Nat. Chem. 2009, 1, 302-309.

(3) Powers, D. C.; Ritter, T. Bimetallic Redox Synergy in Oxidative Palladium Catalysis. Acc. Chem. Res. 2012, 45, 840-850.

(4) Fernando, R. G.; Gasery, C. D.; Moulis, M. D.; Stanley, G. G. Homo- and Heterobimetallic Complexes in Catalysis:Cooperative Catalysis; Springer International: Cham, Switzerland, 2016; pp 1-29.

(5) Che, C.-M.; Schaefer, W. P.; Gray, H. B.; Dickson, M. K.; Stein, P. B.; Roundhill, D. M. Novel Binuclear Platinum(III) Octaphosphite Complexes. J. Am. Chem. Soc. 1982, 104, 4253-4255.

(6) Roundhill, D. M.; Gray, H. B.; Che, C.-M. Pyrophosphitobridged Diplatinum Chemistry. Acc. Chem. Res. 1989, 22, 55-61.

(7) Sicilia, V.; Baya, M.; Borja, P.; Martín, A. Oxidation of HalfLantern $\mathrm{Pt}_{2}$ (II,II) Compounds by Halocarbons. Evidence of Dioxygen Insertion into a $\mathrm{Pt}(\mathrm{III})-\mathrm{CH}_{3}$ Bond. Inorg. Chem. 2015, 54, 73167324.

(8) Tejel, C.; Ciriano, M. A.; Edwards, A. J.; Lahoz, F. J.; Oro, L. A. Metal Basicity of Dirhodium and Diiridium Complexes Induced by Isocyanide Ligands. Model for the Oxidative-Addition reaction of Methyl Iodide with Dinuclear Complexes. Organometallics 1997, 16, 45-53 and references therein..

(9) Sakai, K.; Sato, T.; Tsubomura, T.; Matsumoto, K. Di-(mpyrazolato-N:N')-bis $\left[\left(2,2^{\prime}\right.\right.$-bipyridineN,N')platinum(II)] Bis(tetrafluoroborate) Monohydrate. Acta Crystallogr., Sect. C: Cryst. Struct. Commun. 1996, C52, 783-786.

(10) Umakoshi, K.; Kimura, K.; Kim, Y. H.; Tsukimoto, Y.; Arikawa, Y.; Onishi, M.; Ishizaka, S.; Kitamura, N. Pyrazolato- and 3,5Dimethylpyrazolato-Bridged Dinuclear Platinum(II), Palladium(II), and Their Mixed-Metal Complexes of 2,2'-Bipyrimidine. Syntheses, Structures, and Luminescent Properties. Bull. Chem. Soc. Jpn. 2010, 83, 1504-1510.

(11) Ghavale, N.; Wadawale, A.; Dey, S.; Jain, V. K. Synthesis, Structures and Spectroscopic Properties of Platinum Complexes Containing Orthometalated 2-phenylpyridine. J. Organomet. Chem. 2010, 695, 1237-1245.

(12) Lai, S.-W.; Chan, M. C. W.; Cheung, K.-K.; Peng, S.-M.; Che, C.-M. Synthesis of Organoplatinum Oligomers by Employing NDonor Bridges with Predesigned Geometry: Structural and Photophysical Properties of Luminescent Cyclometalated Platinum(II) Macrocycles. Organometallics 1999, 18, 3991-3997.

(13) Sun, Q.-F.; Wong, K. M.-C.; Liu, L.-X.; Huang, H.-P.; Yu, S.-Y.; Yam, V. W.-W.; Li, Y.-Z.; Pan, Y.-J.; Yu, K.-C. Self-Assembly, Structures, and Photophysical Properties of 4,4'-Bipyrazolate-Linked Metallo-Macrocycles with Dimetal Clips. Inorg. Chem. 2008, 47, 2142-2154. 
(14) Chang, S.-Y.; Chen, J.-L.; Chi, Y.; Cheng, Y.-M.; Lee, G.-H.; Jiang, C.-M.; Chou, P.-T. Blue-Emitting Platinum(II) Complexes Bearing both Pyridylpyrazolate Chelate and Bridging Pyrazolate Ligands: Synthesis, Structures, and Photophysical Properties. Inorg. Chem. 2007, 46, 11202-11212.

(15) Moon, S.; Horiuchi, S.; Sakuda, E.; Ito, A.; Arikawa, y.; Umakoshi, K. Synthesis and Photophysical Properties of ButterflyShaped Dinuclear Pt(II) Complex Having NHC-based Chelate Ligands. Inorg. Chim. Acta 2019, 493, 43-48.

(16) Ma, B.; Li, J.; Djurovich, P. I.; Yousufuddin, M.; Bau, R.; Thompson, M. E. Synthetic Control of Pt $\cdots \mathrm{Pt}$ Separation and Photophysics of Binuclear Platinum Complexes. J. Am. Chem. Soc. 2005, 127, 28-29.

(17) Ma, B. W.; Djurovich, P. I.; Garon, S.; Alleyne, B.; Thompson, M. E. Platinum Binuclear Complexes as Phosphorescent Dopants for Monochromatic and White Organic Light-Emitting Diodes. Adv. Funct. Mater. 2006, 16, 2438-2446.

(18) Chakraborty, A.; Deaton, J. C.; Haefele, A.; Castellano, F. N. Charge-Transfer and Ligand-Localized Photophysics in Luminescent Cyclometalated Pyrazolate-Bridged Dinuclear Platinum(II) Complexes. Organometallics 2013, 32, 3819-3829.

(19) Brown-Xu, S. E.; Kelley, M. S. J.; Fransted, K. A.; Chalcraborty, A.; Schatz, G. C.; Castellano, F. N.; Chen, L. X. Tunable Excited-State Properties and Dynamics as a Function of Pt-Pt Distance in Pyrazolate-Bridged Pt(II) Dimers. J. Phys. Chem. A 2016, 120, 543-550.

(20) Han, M. G.; Tian, Y.; Yuan, Z.; Zhu, L.; Ma, B. W. A Phosphorescent Molecular "Butterfly" that undergoes a Photoinduced Structural Change allowing Temperature Sensing and White Emission. Angew. Chem., Int. Ed. 2014, 53, 10908-10912.

(21) Zhou, C.; Tian, Y.; Yuan, Z.; Han, M.; Wang, J.; Zhu, L.; Tameh, M. S.; Huang, C.; Ma, B. Precise Design of Phosphorescent Molecular Butterflies with Tunable Photoinduced Structural Change and dual Emission. Angew. Chem., Int. Ed. 2015, 54, 9591-9595.

(22) Zhou, C. K.; Yuan, L.; Yuan, Z.; Doyle, N. K.; Dilbeck, T.; Bahadur, D.; Ramakrishnan, S.; Dearden, A.; Huang, C.; Ma, B. W. Phosphorescent Molecular Butterflies with Controlled PotentialEnergy Surfaces and Their Application as Luminescent Viscosity Sensor. Inorg. Chem. 2016, 55, 8564-8569.

(23) Saito, K.; Nakao, Y.; Sakaki, S. Theoretical Study of PyrazolateBridged Dinuclear Platinum(II) Complexes: Interesting Potential Energy Curve of the Lowest Energy Triplet Excited State and Phosphorescence Spectra. Inorg. Chem. 2008, 47, 4329-4337.

(24) Pinter, P.; Unger, Y.; Strassner, T. Cyclometalated NHeterocyclic Carbene Platinum(II) Complexes with Bridging Pyrazolates: Enhanced Photophysical Properties of Binuclear Blue Emitters. Chemphotochem 2017, 1, 113-115.

(25) Arnal, L.; Fuertes, S.; Martín, A.; Baya, M.; Sicilia, V. A Cyclometalated N-Heterocyclic Carbene: The Wings of the First $\mathrm{Pt}_{2}$ (II,II) Butterfly Oxidized by $\mathrm{CHI}_{3}$. Chem. - Eur. J. 2018, 24, 18743-18748.

(26) Nabavizadeh, S. M.; Sepehrpour, H.; Kia, R.; Rheingold, A. L. Bis(diphenylphosphino)acetylene as Bifunctional Ligand in Cycloplatinated Complexes: Synthesis, Characterization, Crystal Structures and Mechanism of MeI Oxidative Addition. J. Organomet. Chem. 2013, 745-746, 148-157.

(27) Nabavizadeh, S. M.; Aseman, M. D.; Ghaffari, B.; Rashidi, M.; Hosseini, F. N.; Azimi, G. Kinetics and Mechanism of Oxidative Addition of MeI to Binuclear Cycloplatinated Complexes Containing Biphosphine Bridges: Effects of ligands. J. Organomet. Chem. 2012, $715,73-81$.

(28) Jamali, S.; Nabavizadeh, S. M.; Rashidi, M. Binuclear Cyclometalated Organoplatinum Complexes Containing 1,1'-Bis(diphenylphosphino)ferrocene as Spacer Ligand: Kinetics and Mechanism of MeI Oxidative Addition. Inorg. Chem. 2008, 47, $5441-5452$.

(29) Pregosin, P. S. Platinum-195 nuclear magnetic resonance. Coord. Chem. Rev. 1982, 44, 247-291.
(30) Roundhill, D. M.; Dickson, M. K.; Atherton, S. J. Thermal and photochemical addition of alkyl and aryl halides to tetrakis $(\mu$ pyrophosphito) diplatinum(II) tetraanion. J. Organomet. Chem. 1987, 335, 413-422.

(31) Ciriano, M. A.; Pérez-Torrente, J. J.; Oro, L. A. Synthesis and reactivity of binuclear 7 -azaindolate complexes of iridium: II. Oxidative-addition reactions of halogens and halocarbons to $[\{\operatorname{Ir}(\mu$ aza) $\left.(\mathrm{CO})_{2}\right\}_{2}$ ]. J. Organomet. Chem. 1993, 445, 273-281.

(32) Caspar, J. V.; Gray, H. B. Photoinduced oxidative addition chemistry of bis(1,5-cyclooctadiene $)$ bis $(\mu$-pyrazolyl)diiridium(I). $J$. Am. Chem. Soc. 1984, 106, 3029-3030.

(33) Vogler, A.; Kunkely, h. Photooxidation of 1,2-dithiolene Complexes of Nickel, Palladium and Platinum in Chloroform. Inorg. Chem. 1982, 21, 1172-1175.

(34) van Slageren, J.; Klein, A.; Zalis, S. Ligand-to-ligand charge transfer states and photochemical bond homolysis in metal-carbon bonded platinum complexes. Coord. Chem. Rev. 2002, 230, 193-211.

(35) Wang, Y.; Verma, P.; Jin, X.; Truhlar, D. G.; He, X. Revised M06 Density Functional for Main-Group and Transition-Metal Chemistry. Proc. Natl. Acad. Sci. U. S. A. 2018, 115, 10257-10262.

(36) From the expression $\Delta G^{\circ} /-R T=\ln [\mathbf{1 - f}] /[\mathbf{1 - s}]$, it can be deduced that as the temperature is decreased [1-f] decreases as well.

(37) Fuertes, S.; Chueca, A. J.; Martín, A.; Sicilia, V. New NHC Cycloplatinated Compounds. Significance of the cyclometalated Group on the Electronic and emitting Properties of Biscyanide Compounds. J. Organomet. Chem. 2019, 889, 53-61.

(38) Hoggard, P. E.; Vogler, A. The photooxidation of tetrachloroplatinate(II) in chloroform. Inorg. Chim. Acta 2003, 348, 229-232.

(39) Sandrini, D.; Maestri, M.; Balzani, V.; Chassot, L.; von Zelewsky, A. Photochemistry of the Orthometalated cis-Bis-[2-(2thienyl)pyridine]platinum(II) Complex in halocarbon Solvents. J. Am. Chem. Soc. 1987, 109, 7720-7724. 